University at Buffalo School of Law

Digital Commons @ University at Buffalo School of Law

$10-16-2020$

\title{
May It Please the Court: A Longitudinal Study of Judicial Citation to Academic Legal Periodicals
}

Brian T. Detweiler

University at Buffalo School of Law, briandet@buffalo.edu

Follow this and additional works at: https://digitalcommons.law.buffalo.edu/law_librarian_articles

Part of the Courts Commons, Law Librarianship Commons, and the Legal Writing and Research Commons

\section{Recommended Citation}

Brian T. Detweiler, May It Please the Court: A Longitudinal Study of Judicial Citation to Academic Legal Periodicals, 39 Legal Ref. Servs. Q. 87 (2020).

Available at: https://digitalcommons.law.buffalo.edu/law_librarian_articles/51

C. IN COPYRIGHT

This Article is brought to you for free and open access by the Law Librarian Scholarship at Digital Commons @ University at Buffalo School of Law. It has been accepted for inclusion in Law Librarian Journal Articles by an authorized administrator of Digital Commons @ University at Buffalo School of Law. For more information, please contact lawscholar@buffalo.edu. 


\title{
May It Please the Court: A Longitudinal Study of Judicial Citation to Academic Legal Periodicals
}

\author{
Brian T. Detweiler, Charles B. Sears Law Library, University at Buffalo \\ School of Law, Buffalo, New York, USA \\ *This is a draft, which was published in 39 Legal Reference Services Q. 87 \\ (2020)
}

\begin{abstract}
This first part of this article examines the citation of American academic law journals in reported opinions from all U.S. state and federal courts from 1945-2018. The study shows a steady rise in the proportion of reported cases that cite at least one academic legal periodical from $1.8 \%$ in 1945 to a peak of $4.9 \%$, first in 1967, and again in 1974 and 1975. Citation rates decreased from thereon, falling to a low of $1.5 \%$ of reported cases from $2005-2010$ before rebounding slightly in recent years.
\end{abstract}

Part II of this article compares judicial citations from 1970-2018 for articles published in Harvard Law Review and Yale Law Journal, the two longest running student-edited journals ${ }^{1}$ at arguably the two most elite law schools in the United States, ${ }^{2}$ with articles published in flagship journals for each of the four "tiers" from the U.S. News \& World Reports "Best Law Schools" rankings, and three exemplar schools from the "Top 14."

This study shows that as the percentage of reported cases citing to at least one academic law journal article has decreased since the mid-1970s, so too has the proportion of reported cases citing to the leading journals of the elite law schools included in this study. At the same time, citation rates for law reviews of exemplar schools for Tiers I-IV remained relatively stable throughout. This paper attempts to explore and explain these trends in the context of changes in technology, the judiciary, legal scholarship, and academic legal publishing.

\section{INTRODUCTION}

It has been nearly ten years since Chief Justice Roberts's now famous quip at the expense of law reviews:

\footnotetext{
${ }^{1}$ Michael I. Swygert \& Jon W. Bruce, The Historical Origins, Founding, and Early Development of Student-Edited Law Reviews, 36 HASTINGs L.J. 739, 779 (1985).

2 See Patrick J. Glen, Harvard and Yale Ascendant: The Legal Education of the Justices from Holmes to Kagan, 58 UCLA L. REV. DisCoURSE 129, 139-44 (2010) (exploring potential explanations for the confirmation of Harvard and Yale graduates, exclusively, for positions on the United States Supreme Court since 1986, and predicting that "the dominance of these two schools will most likely continue into the future, even if it is not quite as pronounced as it is in the present").
} 
"Pick up a copy of any law review that you see and the first article is likely to be, you know, the influence of Immanuel Kant on evidentiary approaches in Eighteenth Century Bulgaria or something, which I'm sure was of great interest to the academic that wrote it, but isn't of much help to the bar."3

While Chief Justice Roberts was hardly the first member of the judiciary to question the utility of law reviews, ${ }^{4}$ his stature stoked further discussion in a debate over their value that is as old as academic law reviews themselves. ${ }^{5}$ The Chief Justice's comments also coincided with the end of the five-year-long nadir for judicial citation of academic legal periodicals in this study, with the proportion of all reported opinions citing to law reviews having fallen steadily since their peak in the mid1970s.

In addition to the overall proportion of opinions citing to academic law journals, this article examines the proportion of cases citing to the two longest running studentedited academic legal periodicals, Harvard Law Review and Yale Law Journal with three exemplar schools from the "Top 14," and each of the four "tiers" of the U.S. News \& World Reports "Best Law Schools" rankings. The findings in this study suggest that the citation advantage enjoyed by Harvard, Yale, and other "elite" law schools has also decreased since the 1970s while citation rates to journals from law schools in Tiers I-IV of the rankings have remained consistent.

This article will begin with a brief look at the history of student-edited law reviews in the United States and how their initially cool reception gradually gave way to acceptance by the judiciary. This study begins in 1945 and explores the gradual increase in the proportion of opinions citing law reviews that would reach its zenith in the 1960s and 70s, followed by a steady decline thereafter. I believe this trend can be explained, in large part, by an increase in both judicial caseload and the number of opinions, changes in technology that facilitated research and access to those opinions, and changes in scholarship that made law reviews seem less relevant to the bench and bar.

\footnotetext{
${ }^{3}$ John Roberts, A Conversation with Chief Justice Roberts, C-SPAN (June 25, 2011), https://www.cspan.org/video/?300203-1/conversation-chief-justice-roberts (30:42-32:14). In addition to stirring debate, Chief Justice Roberts's remarks prompted publication of a tongue in cheek article about his hypothetical topic: Orin S. Kerr, The Influence of Immanuel Kant on Evidentiary Approaches in Eighteenth Century Bulgaria, 18 THE GREEN BAG 2D 251 (2015).

${ }^{4}$ See, e.g., infra notes 19-20 and accompanying text.

${ }^{5}$ See Swygert \& Bruce, supra note 1, at 764-66 (quoting The Albany Law School Journal, 3 CENT. L.J. 136 (1876)) (noting the cool reception received by the first student-edited legal periodical at the hands of commercial journal editorial boards: "'The boys at the Albany Law School have had the enterprise to start a new journal,' wrote the Central Law Journal on February 25, 1876, adding, 'Altogether it is quite creditable. Of course it is not a man's journal."').
} 
Part II of this article begins by comparing citations to flagship journals from Harvard and Yale with those of other law schools representing the "Top 14" and each of the four tiers of the U.S. News Rankings. The data shows a significant decline in citation to the elite law schools' law reviews since the $1970 \mathrm{~s}$, but a persistent bias in favor of these journals remains. The article explores these changes in citation frequency in the context of continued elitism in the legal profession and amid changes in technology and legal publishing that have narrowed these discrepancies.

\section{PART I: CITATION OF ACADEMIC LAW REVIEWS BY THE JUDICIARY}

\section{EARLY LAW REVIEWS}

By the late Nineteenth Century, legal periodicals had become an important part of American legal publishing, allowing lawyers to monitor recent opinions and keep abreast of changes in the law. ${ }^{6}$ Until the launch of the Albany Law School Journal in 1875, these efforts were entirely in the hands of professional editors. ${ }^{7}$ This journal, and another started by law students at Columbia were short-lived, but they laid the groundwork for students at Harvard Law School to follow in their footsteps by founding the Harvard Law Review in 1887. ${ }^{8}$ Four years later, their peers in New Haven launched the Yale Law Journal, followed by the establishment of law reviews at Pennsylvania, Columbia, and Michigan. ${ }^{9}$ Perhaps not coincidentally,

\footnotetext{
${ }^{6}$ Roger C. Cramton, The Most Remarkable Institution: The American Law Review, 36 J. LEGAL EDUC. 1, 2 (1986). See also Swygert \& Bruce, supra note 1, at 751-63 (describing the development of commercial legal periodicals in the United States) and FREDERICK C. HICKS, MATERIALS AND Methods of LEGAL RESEARCH 215 (3d ed. 1942) (quoting Charles E. Grinnell, General Notes, 15 AM. L. REV. 806 (1881)) ("By 1881, writers began to speak of our periodical law press as 'now fast developing into a valuable substitute for a national system of law.'").

7 See Michael I. Swygert, Imitating the 'Boys' of Albany: The Birth of the Valparaiso University Law Review, 25 VAL. U. L. REV. 157, 158-60 (1991) (discussing responses to the early student-edited journals at Albany and Columbia); see also HICKS, supra note 6, at 207 (listing publication date ranges for early law school periodicals). For a description of a surviving issue of the Albany Law School Journal, see Robert A. Emery, The Albany Law School Journal: The Only Surviving Copy, 89 L. LIBR. J. 463, 464-65 (1997) (noting its content more closely resembles a student newspaper than an academic law review).

${ }^{8}$ Cramton, supra note 6, at 3-4; see also Swygert \& Bruce, supra note 1, at 768-69 ("Although there is no evidence that [the] Harvard editors were aware of the earliest student-edited periodical, the Albany Law School Journal, they certainly were familiar with the Columbia Jurist . . [and their] knowledge of the Columbia students' venture in legal journalism surely contributed to the overall concept of the Harvard publication.").

${ }_{9}$ Swygert \& Bruce, supra note 1, at 782-84 (noting also that law reviews at both Michigan and Northwestern were initially edited by faculty).
} 
these longest-running academic journals are associated with many of today's elite law schools. 10

\section{FIRST CITATIONS IN CASE LAW}

While law reviews may have found avid readership among their alumni and utility to members of the profession, ${ }^{11}$ judicial citation of journals was exceedingly rare during the late nineteenth and early twentieth centuries. ${ }^{12}$ The earliest instance of a substantive citation to a legal periodical, rather than simply citing a case reported in a journal, came from an 1857 Supreme Court of Indiana case. ${ }^{13}$ In reaching their conclusion that a municipality had authority to purchase stocks in a railroad that ran through the city, the Court cited to the lead article from an 1854 issue of the American Law Register that argued in favor of state sovereignty over its navigable waterways, and in turn, the delegation of that legislative authority to its municipalities. ${ }^{14}$

Since the American Law Register was professionally edited at the time, not being published by the University of Pennsylvania Law School until 1896, ${ }^{15}$ I investigated further and found what I believe to be the first citation to a student-edited legal periodical in American case law, an 1890 North Carolina Supreme Court opinion in which the judge refers to a Harvard Law Review article by Christopher Columbus

\footnotetext{
10 See, e.g., 2021 Best Law Schools, U.S. NEWS \& WORLD REPORT, https://www.usnews.com/bestgraduate-schools/top-law-schools/law-rankings (last visited July 7, 2020) (each of these law schools falls within the "Top 10" of the most recent rankings) and Lowell J. Noteboom \& Timothy B. Walker, The Law Review-Is It Meeting the Needs of the Legal Profession?, 44 DENV. L.J. 426, 447 (1967) ("[T]he law reviews at Harvard, Yale, Columbia, Pennsylvania, etc. have been around for a long time, and they are associated with law schools that established themselves early as excellent institutions in the field of legal education. It is primarily because they were the first in the field to do a good job (or any job at all) that they initially rose to positions of leadership.").

${ }_{11}$ See e.g., Swygert \& Bruce, supra note 1, at 773 (noting the first issue of the Harvard Law Review had around 300 subscribers, and that by 1890, the Harvard Law Association began purchasing copies for all of its members). By the turn of the century, heavy demand for early copies of the Review necessitated an extensive reprinting effort. Id. at 779 (citing 15 HARV. L. REV. 219 (1901)). 12 See Lawrence M. Friedman et al., State Supreme Courts: A Century of Style and Citation, 33 STAN. L. REV. 773, 811 (finding percentage of state supreme courts citing to law reviews remained between 0.3 and 0.5 percent from 1870 through 1925).

${ }^{13}$ City of Aurora v. West and Another, 9 Ind. 74, 1857 Ind. LEXIS 482 (1857).

${ }^{14}$ Id. at 82 (citing Are State Bridges Constitutional?, 3 AMER. L. REGISTER 1 (1854)). The article was not quoted in the opinion, but states, "if Pennsylvania cannot affect the destination of the Schuylkill, because goods are carried on it to other states, a fortiori it cannot control the employment of the streets of Philadelphia ... over which a commerce to other States of immensely greater value, daily passes; nor can it authorize the city corporation to make municipal regulations for that purpose ... If the argument be correct, indeed, nothing is left in the states to legislate over." Id. at 24.

${ }^{15}$ Swygert \& Bruce, supra note 1, at 756. The American Law Register, was renamed the University of Pennsylvania Law Review in 1896, and has the distinction of being "the oldest continually published legal periodical in America." Id. at 781.
} 
Langdell to explain a concept that was "so familiar ... [it was] hardly necessary to illustrate [it] by reference to actual cases." 16

The U.S. Supreme Court, meanwhile, would not cite to a student-edited journal until Justice Edward White's dissent in an 1897 contracts case, United States $v$. Trans-Missouri Freight Ass' $n,{ }^{17}$ followed three years later by the Court's first law review citation in a majority opinion. ${ }^{18}$ Even then, law reviews were not widely accepted, as Justice Oliver Wendell Holmes would dismiss them as the "work of boys" a decade later, when an attorney referred to them during oral argument. ${ }^{19} \mathrm{As}$ late as the 1920s, Chief Justice William Howard Taft "chided his colleagues (principally Holmes, Brandeis, and Stone) for the 'undignified' use of law review material in their dissents." 20

\section{ACCEPTANCE AND APPROBATION}

By then however, the sentiments of the judiciary had already begun to change, led by luminaries like Justices Brandeis and Cardozo, and Judge Learned Hand, ${ }^{21}$

\footnotetext{
${ }^{16}$ Hancock et al. v. Wooten et al., 12 S.E. 199, 201, 107 N.C. 9, 20 (1890) (citing C.C. Langdell, $A$ Brief Survey of Equity Jurisdiction: Creditors' Bills, 3 HARV. L. REV. 99 (1890)) ("Bills of this kind are called 'Judgment Creditors' Bills' (see Harvard Law Review, October 1890), and are so familiar in our practice that it is hardly necessary to illustrate them by reference to actual cases.").

${ }_{17}$ Swygert \& Bruce, supra note 1, at 788 (citing U.S. v. Trans-Mo. Freight Ass'n., 166 U.S. 290, 350 n.1 (1897)).

${ }_{18}$ Michael L. Closen \& Robert J. Dzielak, The History of the Law Review Institution, 30 AKRON L. REv. 15, 26 (1996) (citing Chi., Milwaukee \& St. Paul Ry. Co., 178 U.S. 353, 365 (1900)). In a unanimous opinion, Chief Justice Melville Fuller cited a discussion on partial payment in satisfaction of a debt appearing in an 1899 Harvard Law Review article. Id. (citing James Barr Ames, Two Theories of Consideration, 12 HARV. L. REV. 515, 521 (1899)).

${ }^{19}$ Charles E. Hughes, Foreword, 50 YALE L.J. 737, 737 (1941). Interestingly, despite his later criticism, Holmes authored the lead articles in two issues of the Harvard Law Review several years prior: Oliver Wendell Holmes, Jr., Agency, 5 HARV. L. REV. 1 (1891) and Oliver Wendell Holmes, Jr., Privilege, Malice, and Intent, 8 HARV. L. REV. 1 (1894); see also Wes Daniels, "Far Beyond the Law Reports": Secondary Source Citations in United States Supreme Court Opinions, 76 L. LIBR. J. 1, 910, 15 (1983) (finding only one citation to a law review during the October 1900 Supreme Court Term and concluding, "it obviously was not considered acceptable for Supreme Court Justices to refer to [legal periodicals] at the turn of the century.").

20 John W. Johnson, The Dimensions of Non-Legal Evidence In The AMERICAN Judicial Process 133 (1990) (quoting Alpheus T. MASOn, William Howard TAFT 268-69 (1965)). See also Chester A. Newland, Legal Periodicals and the United States Supreme Court, 7 U. KAN. L. REV. 477, 479 (1959) (in a study of Supreme Court opinions from the October Term of 1924 through the October Term of 1956, Chief Justice Taft cited a legal periodical only once, and Justice Holmes only twice; Brandeis, and Stone were both more apt to cite law reviews, citing them 19 and 21 times, respectively, during that period).

${ }^{21}$ See id.; see also Douglas B. Maggs, Concerning the Extent to Which the Law Review Contributes to the Development of the Law, 3 S. CAL. L. REV. 181, 186 n.11a (1930) (quoting Circuit Judge Learned Hand, Justice Benjamin Cardozo, then Chief Judge of the New York Court of Appeals, and Chief Justice Robert von Moschzisker of the Pennsylvania Supreme Court on the usefulness of law reviews in the performance of their judicial duties and their willingness to cite them in their opinions) and
} 
although the proportion of opinions citing to law reviews around this time still remained well below their lowest point in this study. ${ }^{22}$ In 1941, Taft's successor, Chief Justice Charles Hughes, struck a far more positive tone in a foreword composed in honor of the 50th Anniversary of the Yale Law Journal, where he described law reviews as the "fourth estate of the law" and said, "[i]t is not too much to say that, in confronting any serious problem, a wide-awake and careful judge will at once look to see if that subject has been discussed, or the authorities collated and analyzed, in a good legal periodical." 23

\section{METHODOLOGY}

To determine the total number of opinions in Lexis for a given year, I ran a search for that year in Lexis Advance's "Cases" database and restricted my results by date to that year alone. For example, by searching ("1972") \& DA(aft 12-31-1971 \& bef 01-01-1973), and selecting "Publication Status" from the menu on the left, I found 59,320 reported opinions for 1972 . I could then add the reported and unreported numbers together to determine the total number of opinions in Lexis for that year, in this case 60,758; however, I assumed researchers would be most interested in seeing how journals were cited in reported opinions, so I focused my data gathering efforts on those results. ${ }^{24}$

In the interests of readability, the searching and data compilation methodologies I employed for Part I are included as Appendix A. That section recounts my attempt

Frederick E. Crane, Law School Reviews and the Courts, 4 FoRDHAM L. REV. 1, 3 (1935) (Chief Judge Crane of the New York Court of Appeals wrote in a symposium piece for Fordham Law Review, "[law reviews have] supplemented the textbook and the decision because we have found from experience that the modern law professor ... has had time as well as desire to enter thoroughly into the study of a particular subject and has given the result of his efforts for the benefit of the profession ... we of the bench, as well as the lawyer at the bar, should make this acknowledgement, though somewhat belated, of the help which we get from [law reviews] in the disposition of the every-day work of the courts.").

22 Douglas B. Maggs, supra note 21, at 191-94 (examining federal and state reported opinions from a roughly one year period in the late 1920s and U.S. Supreme Court opinions from 1924-1928, and finding only 80 opinions out of an estimated total of 30,000 [0.27\%], and 61 out of approximately 850 judges citing law reviews.) Another study of state supreme courts found the percentage of opinions citing to law reviews remained between $0.3 \%$ and $0.5 \%$ between $1870-1925$ before increasing to $2.3 \%$ from $1930-40,3.8 \%$ from $1945-55$, and finally $11.9 \%$ from $1960-70$, with the "innovative" supreme courts from New Jersey and California leading the way. Friedman et al., supra note 12 at 811, 815.

${ }^{23}$ Hughes, supra note 19, at 737. This change at the U.S. Supreme Court was initially led by Justice Louis Brandeis, and solidified by the nine Justices appointed by President Franklin D. Roosevelt. Closen \& Dzielak, supra note 18 at 27 (citing PhilipPa Strum, Louis D. BRANDEIS: JUsTiCE FOR THE PEOPLE 364 (1984)).

${ }^{24}$ See David L. Schwartz \& Lee Petherbridge, The Use of Legal Scholarship by the Federal Courts of Appeals: An Empirical Study, 96 CoRNELL L. REV. 1345, 1353-54. ("Reported decisions are documents evidencing the law, and thus citation to legal scholarship in reported decisions brings cited scholarship into close relationship with the law."). 
to include all academic journals listed in the Current Index to Legal Periodicals, ${ }^{25}$ the Index to Legal Periodicals Retrospective: 1908-1981 Coverage List, ${ }^{26}$ and the $19^{\text {th }}$ edition of The Bluebook. ${ }^{27}$

\section{A RISING TIDE}

During the first year of my study in 1945, academic law reviews were still only cited in roughly $1.8 \%$ of opinions, but the period following World War II would usher in an era of growth, both in their numbers ${ }^{28}$ and in their citation by the judiciary, as this "remarkable institution" 29 "earned the real respect of the bench." 30 By the early 1960 s, the proportion of cases citing law reviews had increased to nearly four percent of reported opinions. Judge Roger Traynor said at that time, "There is in no other profession and in no other country anything equal to the student-edited American law review," describing law reviews as "the best critics a judge could have." 31

The ensuing years, from 1963 through 1980, witnessed a high-water mark in the judicial citation of academic law reviews in this study, with the proportion of opinions citing journals never falling below $4 \%$, and reaching as high as $4.9 \%$ in 1967,1974 , and 1975 . This peak represents a $172 \%$ increase in opinions citing law reviews since 1945 .

The years following the 1975 peak witnessed a slow and steady decline in the proportion of opinions citing to law reviews in my study as citations fell below $4 \%$ by 1981, below $3 \%$ in 1987 , and below $2 \%$ in 1994 , falling to their lowest proportion in

${ }^{25}$ CILP Journals, HeINONLINE, https://libguides.heinonline.org/c.php?g=1045270\&p=7595542

[https://perma.cc/V2B3-T2FA] (last visited July 6, 2020).

${ }^{26}$ Index to Legal Periodicals Retrospective: 1908-1981 (H.W. Wilson)

Database Coverage List, EBSCO, https://www.ebscohost.com/titleLists/lpr-coverage.htm

[https://www.ebscohost.com/titleLists/lpr-coverage.htm] (last visited July 6, 2020).

27 The Bluebook: A Uniform System of CitATion (Columbia Law Review Ass'n et al. eds., 19th ed. 2010). This was the last edition to include a list of periodicals by title in Table 13.

${ }^{28}$ Barbara H. Cane, The Role of Law Reviews in Legal Education, 31 J. LEGAL EDUC. 215, 220 (1981) (noting an increase in the number of law reviews from 44 in 1941 to 78 in 1955, 102 in 1966, and 182 in 1979).

${ }^{29}$ Earl Warren, Messages of Greeting to the U.C.L.A. Law Review, 1 UCLA L. REV. 1 (1953).

30 Stanley H. Fuld, A Judge Looks at the Law Review, 28 N.Y.U. L. REV. 915, 918 (1953) ("We admire the law review for its scholarship, its accuracy, and, above all, for its excruciating fairness. We are well aware that the review takes very seriously its role as judge of judges—and to that, we say, more power to you.").

${ }^{31}$ Roger J. Traynor, To the Right Honorable Law Reviews, 10 UCLA L. REV. 3, 8--10 (1962); see also William O. Douglas, Law Reviews and Full Disclosure, 40 WASH. L. REV. 227 (1965) (in an address delivered to members of the Washington Law Review, Justice Douglas relayed his "special affection for law reviews ... [noting he has] drawn heavily from them for ideas and guidance as practitioner, as teacher, and as judge") and Noteboom \& Walker, supra note 10, at 433 (noting that $62.7 \%$ of judges who responded to a 1966 survey found law reviews "quite valuable" for their research versus $16.7 \%$ who felt they had "little or no value"). 
2009 , at $1.47 \%$. This figure represents a $70 \%$ decrease from the mid-1970s. The proportion of opinions citing to law reviews has risen slightly since, however, coming back full circle to reach $1.8 \%$ in 2018 , the same percentage as in 1945 , the first year of this study. Other studies have shown similar patterns in judicial citation of legal scholarship at different points during this time period. ${ }^{32}$

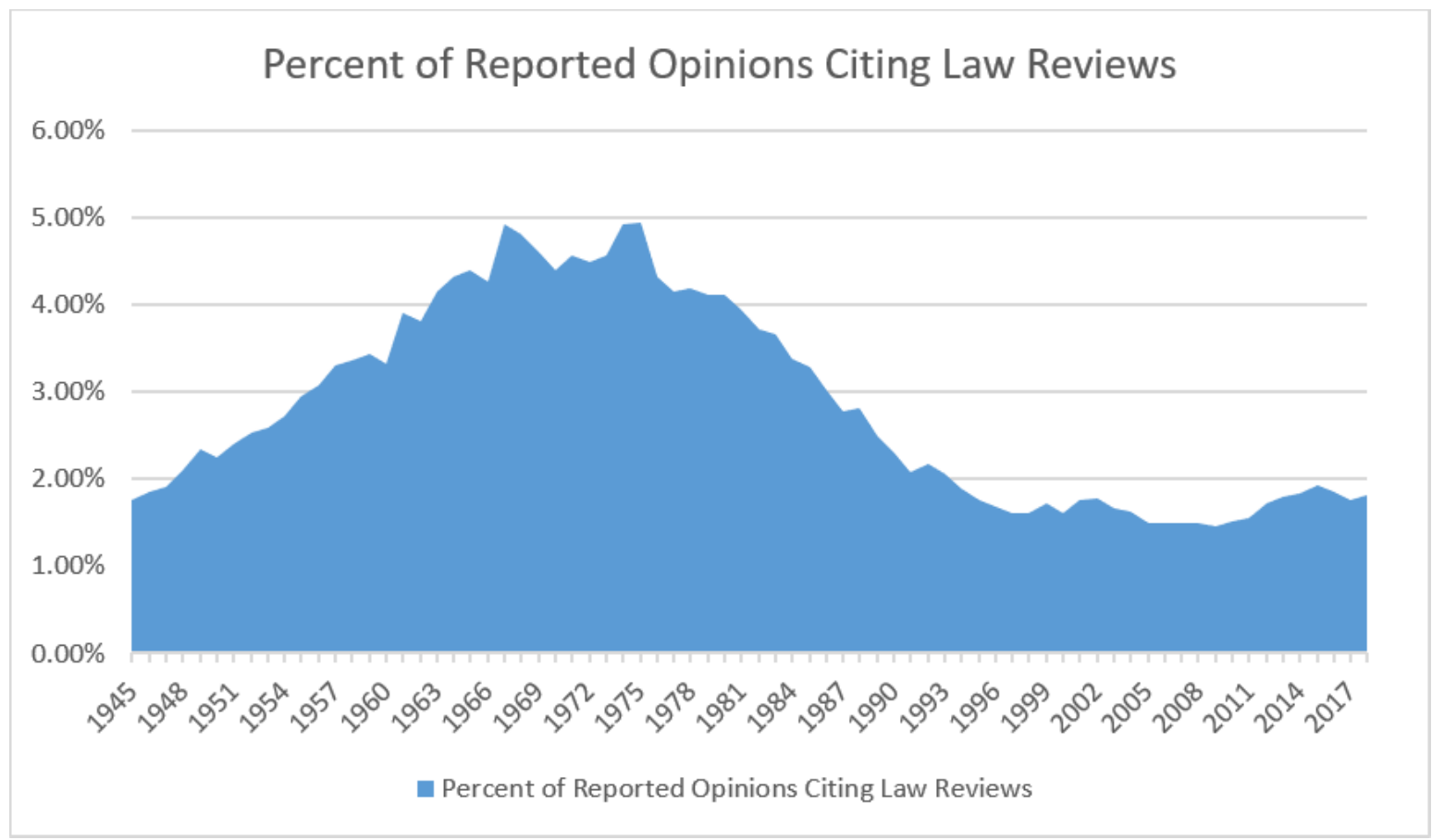

32 See, e.g., Friedman et al., supra note 12 at 811; John H. Merryman, Toward a Theory of Citations: An Empirical Study of the Citation Practice of the California Supreme Court in 1950, 1960, and 1970, 50 S. CAL. L. REV. 381, 405 (1978) (noting an increase in citations to legal periodicals by the California Supreme Court from 87 in 1950 to 164 in 1970); Michael D. McClintock, The Declining Use of Legal Scholarship by Courts: An Empirical Study, 51 OKLA. L. REV. 659 (1998) (in a study of citations to 40 leading law reviews by the U.S. Supreme Court, federal circuit courts, federal district courts, and state supreme courts, the author found quantitative decreases of $58.6 \%, 56.0 \%, 24.8 \%$, and 46.8\%, respectively, between the years 1975-1976 and 1995-1996); Louis J. Sirico Jr., The Citing of Law Reviews by the Supreme Court: 1971-1999, 75 IND. L.J. 1009, 1011-13 (2000) (finding "a steady decline" in both the number and proportion of opinions citing to legal scholarship over four different two-year Supreme Court terms between 1971 and 1998); and Blake Rohrbacher, Decline: Twenty-Five Years of Student Scholarship in Judicial Opinions, 80 AMER. BANKR. L.J. 553 (2006) ("Judicial citation of student notes has plunged since 1980."). Cf. Schwartz \& Petherbridge, supra note 12, at 1363 (authors noted a steady increase in the proportion of opinions citing to legal scholarship from 1950, reaching a high point in in the late 1970s through the early to mid-1980s, followed by a steady decrease through the remainder of the decade before the proportion leveled out around 1990 and "[held] steady at a rate substantially higher than in the earlier years studied."). But see Whit D. Pierce \& Anne E. Reuben, Empirical Study, The Law Review is Dead; Long Live the Law Review: A Closer Look at the Declining Use of Legal Scholarship, 45 WAKE FOREST L. REV. 1185, 1203, 1221-25 (2010) (in a study limited to federal and state court opinions that included headnotes on Westlaw, two Wake Forest law students found proportional increases in the judicial citation of law reviews between the years 1960-1964 and 2005-2009, finding the largest increase among U.S. Supreme Court opinions, from $12.9 \%$ to $31.4 \%$ ). 
The overall quantity of opinions citing to law reviews also increased from the beginning of this study, ultimately reaching its peak of 4,226 in 1983, somewhat later than the proportional peak because the number of reported opinions over that time-115,192 for 1983 versus 71,112 in 1975-outpaced the growth of citations, meaning that the proportion had decreased by 1983 to $3.7 \%$. As with the proportional percentage, the quantity of opinions citing to law reviews also declined fairly consistently after its peak over the ensuing decades. ${ }^{33}$

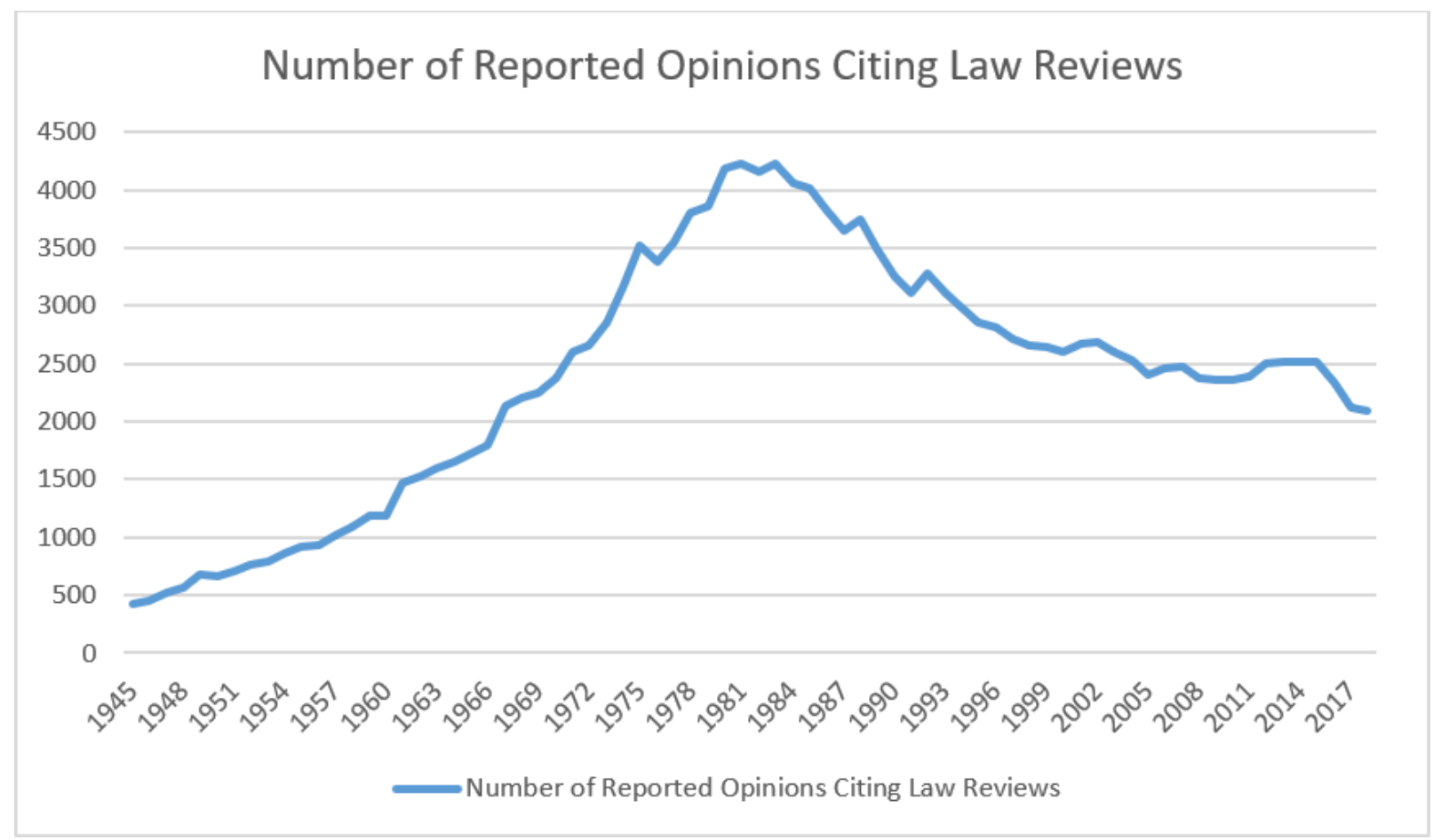

\section{THE TIDE EBBS}

There are several potential explanations for why, after years of growing acceptance and utilization as a source of reference for the courts, law reviews began to fall out of favor. These factors include changes in technology, increases in caseload and case law, and a shift in the legal academy led by the elite law schools that pushed the boundaries of scholarship beyond the scope of matters typically litigated in the courts.

\section{TECHNOLOGY}

From the 1940s through the 1980s, researchers hoping to find law review articles on a particular topic would typically need to consult a periodical index such as Index to

${ }^{33}$ See Figure _, "Number of Reported Opinions Citing Law Reviews"; see also McClintock, supra note 32, at 689 (showing a decline in citations to 40 leading law reviews by all federal courts and state supreme courts from 7,131 in 1975-76 to 6,835 in 1985-86, and finally, 4,108 in 1995-96). 
Legal Periodicals before pulling a physical journal volume from the shelf. ${ }^{34}$ This process began to change in 1982, when Lexis and Westlaw added the text of select law reviews to their searchable databases; ${ }^{35}$ however, the inclusion of additional titles was a gradual process, ${ }^{36}$ and researchers relied primarily on indexes into the 1990s. ${ }^{37}$

At the same time, the ease of locating caselaw through Lexis and Westlaw, introduced in 1973 and 1975, respectively, likely had an ever-greater impact on the decline of journal citation of law reviews as these now ubiquitous databases became increasingly relied upon by the legal profession. ${ }^{38}$ By facilitating the discovery of primary law, these services provided researchers with a viable, and in many ways

34 See Frederick C. Hicks, Materials And Methods of Legal Research 336-37 (3d ed. 1942); see also J. MYron JACOBSTEIN \& ROY M. MERSKY, FundAMENTALS OF LEGAL RESEARCH 314 (1977)

("[T]he usefulness of legal periodicals depends almost entirely on the ability to find out what articles have been written and where they have been published. Generally, it is necessary to rely to indexes to the legal periodical literature for this purpose.").

${ }^{35}$ Howard A. Hood, Disk and Dat: Recent Developments in Legal Databases and Emerging Information Technologies in the United States, 15 INT'L J. L. INFO. 109, 112 (1987) ("LEXIS has added all articles from over thirty journals beginning with their 1982 volume. WESTLAW has selected articles from many more journals for the same period ... [although] [b] ecause of the selectivity of the WESTLAW database, one cannot be sure whether a particular article will be available through that service. (West has recently decided to match [Lexis] in loading all articles from the top legal journals.)").

${ }^{36}$ By the late 1980s, Lexis provided full-text searching of roughly 48 mostly academic law reviews it considered "important," while Westlaw provided access to a broader range of journals, although some with coverage of individual articles only, selected for their importance to legal practice. MORRIS L. COHEN ET AL., How TO FIND THE LAW 376-77 (9th ed. 1989); see also Bernard J. Hibbitts, Last Writes-Reassessing the Law Review in the Age of Cyberspace, 71 N.Y.U. L. REV. 615, 657-58 (1996) (explaining the reasons for the initial exclusion of law reviews, and beginning in 1982, the gradual inclusion of full-text journals into the databases).

37 See Kenneth Lasson, Scholarship Amok: Excesses in the Pursuit of Truth and Tenure, 103 HARV. L. REV. 926, 937 (1990) ("Finding everything that's ever been written on [a] subject requires little more than leafing through the Current Law Index or its older but perfectly adequate counterpart, the Index to Legal Periodicals.") By the mid-1990s this seems to have changed. See Hibbitts, supra note 36, at 658-59 ("Together, LEXIS and WESTLAW have subtly changed the way in which law review material is distributed, accessed, and employed by many members of the American legal community.").

38 See William G. Harrington, A Brief History of Computer-Assisted Legal Research, 77 LAW LIBR. J. 543, 547-53 (1985) (discussing the Ohio Bar Association's attempt to create an "on-line" legal research service that would eventually evolve into Lexis, and the West Publishing Company's subsequent development of Westlaw in response); see also Peter Nycum, Law and Computers: Overview Update 1975, 68 LAW LIBR. J. 234, 247-49 (reviewing databases available, and expected to be made available, to Lexis subscribers by the end of 1975; Lexis offered two subscription plans for access to a single terminal, a $\$ 36,000$ per year plan that provided between 28 and 55 hours of research per month, and a second option for $\$ 18,000$ per year that provided 9-18 hours of search time per month). At the time the article was published, the West Retrieval System, which would begin by offering electronic access to West's General Digest, Fourth Series, was still in testing. Id. at 250. 
superior alternative to using law reviews as a shortcut for their own research. ${ }^{39}$ They also gave judges more opportunity to locate and cite controlling precedent in their opinions in lieu of nonbinding secondary sources like legal periodicals. ${ }^{40}$

This greater discoverability of information applied to nonlegal material as well. ${ }^{41}$ The ease and ubiquity of online searching since the 1990s facilitated the discovery and citation of online sources by both judges and attorneys with multiple studies showing an increase in citation to various nonlegal materials by the courts, ${ }^{42}$ continuing a trend that began even before the advent of the Internet. ${ }^{43}$ Additionally, the consolidation of the legal publishing industry into a few large multinational conglomerates has made nonlegal sources more visible to legal researchers as

39 Pierce \& Reuben, supra note 32, at 1194 ("[W]ith the emergence of the Internet, judges and their clerks have easy, instant access to reams of caselaw. It used to be that law reviews serve as an easy research tool for judges. A judge before he or she wrote an opinion, would use a law review to do just that-review the law. With the advent of the Internet, it makes sense for a judge to cut the middleman out of the research process."); see also, Judith S. Kaye, One Judge's View of Academic Legal Writing, 39 J. LEGAL EDUC. 313, 319 (1989) (Judge Kaye notes reading law reviews for background information in relation to the issues she faces on the New York Court of Appeals, but "do[es] not seek out law review articles for case compilations-we have a variety of manual and computerized research tools for such information."). See also, Lasson, supra note 37, 937 ("With the advent of computerized data banks such as Lexis and Westlaw, gleaning all the cases on point is as easy as playing Trivial Pursuit and maybe even more fun.").

40 James H. Fowler \& Sangick Deon, The Authority of Supreme Court Precedent, 30 Soc. NETwORKS 16, 16 (2008) (citing statements by Justices Ginsburg, Powell, and Stevens in support of the notion that judges, "are aware of the inherent weakness of the federal judiciary and place high value on maintaining their institutional and decisional legitimacy through the use of precedent"); see also David J. Walsh, On the Meaning and Pattern of Legal Citations: Evidence from State Wrongful Discharge Precedent Cases, 31 LAW \& SOC'Y REV. 337, 339 (1997) (offering two "central" reasons for the judicial use of citations: "The first is that citations indicate intercourt communication and influence on judicial decisionmaking ... The second, and contrasting, view is that . . citations are used to justify those decisions... That is, citations are seen as serving a primary function of legitimation.").

${ }^{41}$ Frederick Schauer \& Virginia J. Wise, Nonlegal Information and the Delegalization of Law, 29 J. LEGAL STUD. 495, 510-11 (2000). The quantity of data has also increased exponentially. See Bernard Marr, How Much Data Do We Create Every Day? The Mind-Blowing Stats Everyone Should Read, FORBES, (May 21, 2018), https://www.forbes.com/sites/bernardmarr/2018/05/21/how-much-data-dowe-create-every-day-the-mind-blowing-stats-everyone-should-read/ [https://perma.cc/SE3C-5FBM] ("There are 2.5 quintillion bytes of data created each day at our current pace, but that pace is only accelerating ... Over the last two years alone 90 percent of the data in the word was generated."). 42 See e.g., John J. Hasko, Persuasion in the Court: Nonlegal Materials in Supreme Court Opinions, 94 LAW LIBR. J. 427, 442 (2002) ("[V]irtually every discipline, scientific or not, has become fair game for citation."); Frederick Schauer \& Virginia J. Wise, Nonlegal Information and the Delegalization of Law, 29 J. LEGAL STUD. 495, 496, 509 (2000) (authors found a threefold increase in citation to nonlegal sources by the U.S. Supreme Court from 1990 to 1998, and similar results in a sample of New Jersey Supreme Court opinions over the same period) and Ellie Margolis, Authority without Borders: The World-Wide Web and the Delegalization of the Law, 41 SETON HALL L. REV. 909, 920-21 (2011) (citing several studies finding increased citation of nonlegal materials in judicial opinions). 43 Daniels, supra note 19, at 4 (finding a $416 \%$ increase in the number of citations to secondary sources per opinion and an increase in citation to nonlegal sources of $1,429 \%$ from the 1900 Term to the 1978 Term). 
traditional legal databases like Lexis and Westlaw now provide ready access to more than just traditional primary and secondary legal authority. ${ }^{44}$

\section{INCREASES IN CASE LAW AND CASELOAD}

Beyond the greater ease of locating case law on Lexis and Westlaw, there was also more of it. The exponential increase in the number of published and unpublished opinions over the period of study ${ }^{45}$ meant that as time went on, judges simply had less need to consult law reviews to resolve the issues before them. ${ }^{46}$ As the body of common law continually expands to cover new topics and factual scenarios, judges are more likely to locate relevant opinions to substantiate their decisions, leaving law reviews for difficult cases involving "new or unsettled area[s] of law."47

\footnotetext{
${ }^{44}$ Schauer \& Wise, supra note 41, at 511-13 (comparing the ease of accessing various nonlegal sources through Lexis and Westlaw at the turn of the millennium against the additional steps necessary less than thirty years prior). For example, Lexis Advance now offers access to news, medical and scientific publications, directories, and public records.
}

45 See Figure _, "Number of Opinions in Lexis Advance 1945-2018"; see also Merritt E. McAlister, Downright Indifference: Examining Unpublished Decisions in the Federal Courts of Appeals, 118 MICH. L. REV. 533, 542-46 (2020) (describing the increased caseload and proliferation of unpublished opinions at the federal appellate level since the 1960s, leading to the promulgation of Federal Rule of Appellate Procedure 32.1 expressly authorizing citation of unpublished opinions in the circuit courts as of January 1, 2007).

${ }^{46}$ Pierce \& Reuben, supra note 32, at 1196-97 ("[T] here is, quite simply, little need for a judge to support his or her opinion with a law review article if there is a case on point.").

${ }^{47}$ Id. at 1196 (quoting Alex Kozinski, Who Gives a Hoot About Legal Scholarship?, 37 Hous. L. REV. 295, 296 (2000)) ("[T] he opinions most likely to rely on the works of academics are those written in the gray areas of the law where precedent doesn't provide a clear-cut answer."); see also Thomas L. Ambro, Citing Legal Articles in Judicial Opinions: A Sympathetic Antipathy, 80 AM. BANKR. L.J. 547,549 (2006) (noting that he attempts to dispel the doubt that arises when deciding difficult cases by consulting all "reputable source[s] of information ... This is where articles can play a significant role."). 


\section{Number of Opinions in Lexis Advance 1945-2018}

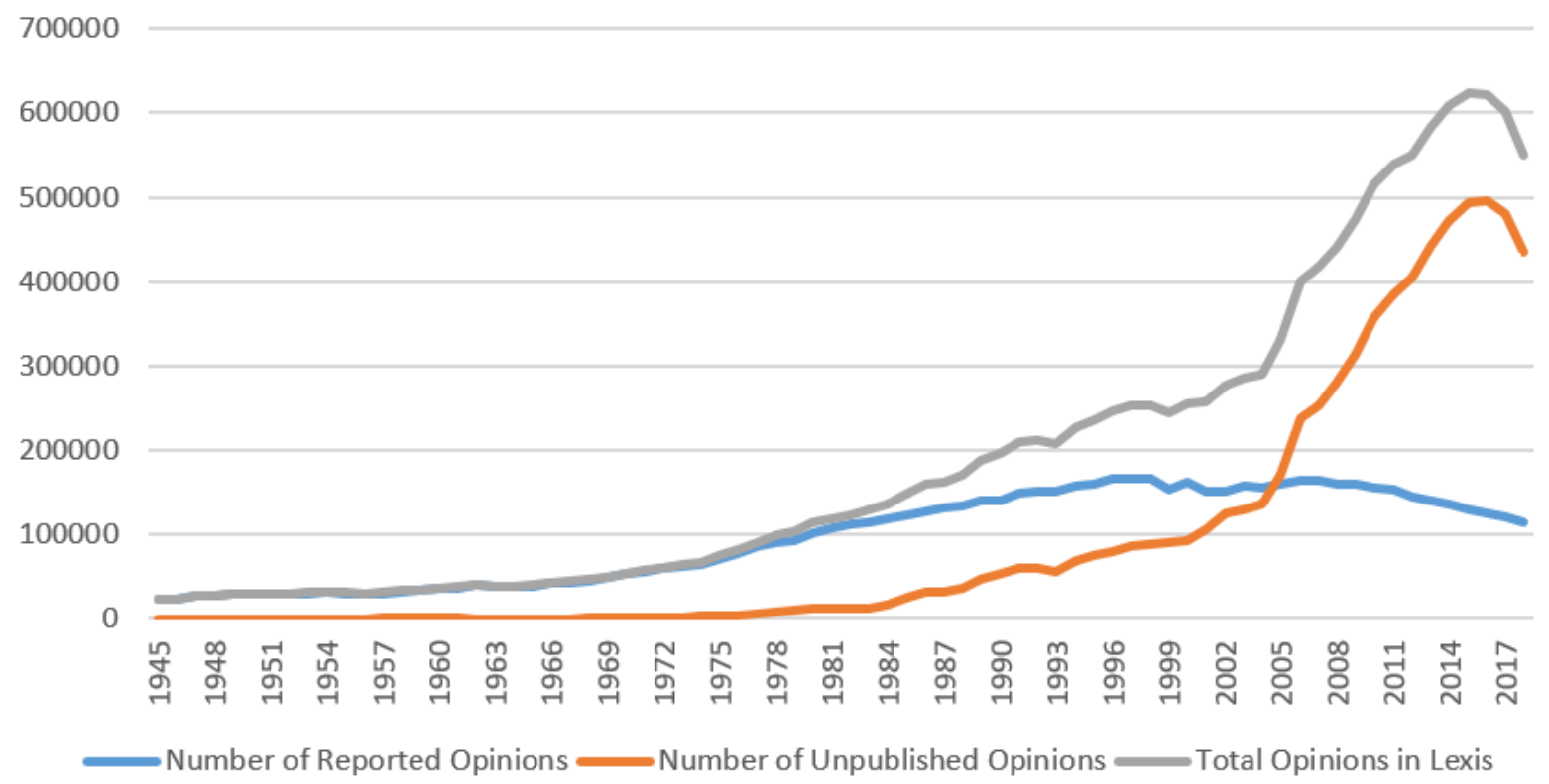

This ever-greater quantity of case law is a direct result of increasing caseloads faced by the judiciary, ${ }^{48}$ and has also likely reduced judges' reliance on legal scholarship, as the data from a 2011 study of federal appellate courts "suggest[ed] that the busier a court is, in terms of the work required of each judge, the less likely it is to cite legal scholarship." 49 This certainly makes sense given that a judge or clerk researching and writing under significant time constraints will likely focus on researching, and thus citing, mandatory authority as opposed to non-binding secondary sources. 50 That the judge may have little faith she will find an article

48 See e.g., Thomas B. Marvell \& Carlisle E. Moody, The Effectiveness of Measures to Increase Appellate Court Efficiency and Decision Output, 21 U. MiCH. J. LEGAL REFORM 415, 415 (1988) (noting that appellate caseloads have doubled approximately every ten years since World War II) and Shay Lavie, Appellate Courts and Caseload Pressure, StAn. L. \& PoL'Y Rev. 57, 59 (2016) (quoting Cathy Catterson, Changes in Appellate Caseload and Its Processing, 48 ARIZ. L. REV. 287 (2006)) (between the years 1971 and 2005, there was "'a 500\% increase in filings, and a 77\% increase in judgeships.' The result is a sizeable increase in the number of cases assigned to each judge."). ${ }^{49}$ Schwartz \& Petherbridge, supra note 12, at 1366 (noting also that other variables beyond a court's workload likely influence citation to legal scholarship); see also McClintock, supra note 32, at 688 (citing Federal Courts Study Comm., Report of THe Federal CourTs Study CommitTee 110 (1990)) (suggesting that an increase in judicial workloads may limit consultation of secondary sources).

${ }^{50}$ See Ambro, supra note 47, at 549 (discussing how time constraints require him to decide issues based on cases cited in briefs or found during the course of his clerks' or his own research); see also Ryan Whalen et al., Common Law Evolution and Judicial Impact in the Age of Information, 9 ELON L. REV. 115, 134 (2017) ("Although there are many aspects of legal research, the search for relevant precedent is the most fundamental form of legal information seeking."). 
addressing the issue she is facing would only disincentivize her further from investing her limited time attempting to locate one.

\section{INCREASINGLY IMPRACTICAL SCHOLARSHIP—AN IVORY TOWER AFTERTHOUGHT}

The student editors of the inaugural issue of the Harvard Law Review shared the aspiration that they were "not without hope that the Review may be serviceable to the profession at large." ${ }^{51} \mathrm{I}$ think it is safe to say they succeeded. From these humble beginnings, their journal and others like it would go on to have a tremendous impact on legal education, the legal profession, and on American society in general. ${ }^{52}$

In the first decades of this study, as the proportion of citations increased, practical scholarship remained an important goal for law reviews as an institution, as service to the "practicing bar and the profession, and through them the nation as a whole" was stressed along with their pedagogical mission within their law schools. ${ }^{53}$ Law reviews became more accepted by the bench and bar as a result of their value to the profession, ${ }^{54}$ while the goal of furthering academic discourse did not merit mention among the primary objectives of law reviews in a 1952 article and was perhaps only considered tangentially in another from $1967 .{ }^{55} \mathrm{~A}$ generation later however, many scholars had increasingly branched out from traditional or "doctrinal" legal scholarship to engage each other in conversations that would largely exclude the judiciary and practitioners. ${ }^{56}$

51 Notes, 1 HARV. L. REV. 35 (1887).

52 See, e.g., William L. Prosser, Privacy, 48 CaL. L. REV. 383, 383 (1960) (citing Samuel D. Warren \& Louis D. Brandeis, The Right to Privacy, 4 HARV. L. REV. 193 (1890)) (calling Warren and Brandeis's article "the outstanding example of the influence of legal periodicals upon the American law") and Newland, supra note 20, 483-88 (listing four other notable instances where law reviews influenced the Supreme Court's legal reasoning).

53 John E. Cribbett, Experimentations in the Law Reviews, 5 J. LEGAL EdUC. 72, 74 (1952); see also Noteboom \& Walker, supra note 10, at 448 (describing the two purposes of the law review as "educational value for the student" and "serv[ing] the profession directly").

54 See supra notes 21-23 and accompanying text. Even then, law reviews were seen more as practical research and teaching tools, not for their value to the reader. See Harold C. Havighurst, Law Reviews and Legal Education, 51 Nw. U. L. REV. 22, 24 (1956) ("Whereas most periodicals are published primarily in order that they may be read, the law reviews are published primarily that they may be written.") and Alan W. Mewett, Reviewing the Law Reviews, 8 J. LEGAL EDUC. 188, 188 (1955) ("Few reviews are read; and although most of them are skimmed over in the hope of finding something worthwhile to read, some perhaps do not even have that honor conferred upon them."). 55 See Cribbet, supra note 53, at 74 and Noteboom \& Walker, supra note 10, at 449 (suggesting that in addition to their educational value and their service to the profession, law reviews "should contribute something more than useless verbiage to the ever-growing volume of legal journalism"). 56 See Laurens Walker, Developments in Law and Social Sciences Research, 52 N.C. L. REV. 969, 969-70 (1974) (citing David F. Cavers, "Non-Traditional" Research by Law Teachers: Returns from 


\section{PUSHBACK AGAINST PRACTICALITY}

This trend away from traditional scholarship began in the 1970s as the elite law schools sought to differentiate themselves from their less-prestigious peers. ${ }^{57}$ And while much scholarship at this time still "reflect[ed] the impact of professional demands upon the academy," 58 as elite institutions increasingly directed their attention towards interdisciplinary studies and new schools of thought rather than matters directly relevant to practice, ${ }^{59}$ their status and outsized influence meant this shift would have a disproportional effect on perceptions of the legal academy and legal scholarship among the bench and bar, even as much useful scholarship continued to be published. 60

the Questionnaire of the Council on Law-Related Studies, 24 J. LEGAL EDUC. 534, 543 (1972)) (observing that "[m]ost legal research to date has been doctrinal in nature . . . typically organize[d] . . . around legal propositions and ... us[ing] appellate court reports and other printed materials readily accessible in law libraries as [the] principal . . source of data," while also noting that approximately one in six full time law faculty members surveyed in 1971 reported participating in "non-traditional" [interdisciplinary] research). A previous study examining the types of articles published in 1967 found only 54 articles out of more than 4,100 were based in empirical research. Noteboom \& Walker, supra note 10, at 442 ("The law reviews have been derelict in the area of empirical research.").

${ }^{57}$ Richard A. Posner, The Present Situation in Legal Scholarship, 90 YALE L.J. 1113, 1118 (1981) (quoting Alumni Weekend, YALE L. REP. 4, 7-8 (1978-79)) (Judge Posner quotes Yale Law School Dean Harry Wellington as saying, "[t]here are a dozen or so university law schools in the country that can properly claim to be more than trade schools. A trade school is an institution that views its purpose a graduating students who will pass a bar examination. Schools that are more than trade schools share this purpose, but they are centrally concerned with the advance of knowledge through teaching and research."); see also Mark Tushnet, Legal Scholarship: Its Causes and Cure, 90 YALE L.J. 1205, 1221 (1981) (discussing Yale Law School's desire to maintain its elite status through cutting edge scholarship).

${ }^{58} I d$. at 1208 . The contemporaneous data supports this assertion, as the proportion and quantity of opinions citing law reviews were at or near their respective peaks in this study.

${ }^{59}$ For a description of the shift towards interdisciplinary studies in the academy, see RICHARD A. Posner, OverComing LAW 84-87 (1995); see also Bernard J. Hibbitts, supra note 36, at 640 (noting the growth of interdisciplinary research and the increasing importance of scholarship beginning in the mid-1970s). A further example of the shift away from practical scholarship at this time is the decline in legal treatise writing. See A.W.B. Simpson, The Rise and Fall of the Legal Treatise: Legal Principles and the Forms of Legal Literature, 48 U. CHI. L. REV. 632, 677-79 (1981) (positing that the growth of legal realism led to the decline in authorship and prestige of treatises).

${ }_{60}$ Michael J. Saks et al., Is There a Growing Gap Among Law, Law Practice, and Legal Scholarship?: A Systematic Comparison of Law Review Articles One Generation Apart, 30 SUfFolK U. L. REv. 353, 370-71 (1996) (finding the ratio of articles perceived as "practical" versus theoretical decreased from 4.88 in 1960 to 1.11 by 1985 , but due to the increase in scholarly output over that time, the actual number of practical articles published increased from 736 to 1,296). 


\section{BACK TO "NO RESPECT AT ALL"61}

By the 1990s, this perception had largely become reality. ${ }^{62}$ And even judges who regularly consulted law reviews for "the newest thinking on [a] subject ... [and their] global yet profound perspective," noted that, "[p]rominent law reviews are increasingly dedicated to abstract, theoretical subjects ... and less and less to practice and professional issues, and to the grist of state court dockets." 63 In the most bellicose of these critiques from the bench at this time, Judge Harry Edwards of the Court of Appeals for the D.C. Circuit, bemoaned the lack of practical scholarship in law reviews, categorizing law professors producing "mediocre interdisciplinary articles" as "ivory tower dilettantes, pursuing whatever subject piques their interest, whether or not the subject merits legal scholarship."64

Judge Richard Posner, who was perhaps the first member of the judiciary to note the shift away from doctrinal analysis at the elite law schools, ${ }^{65}$ agreed that "some

${ }^{61}$ In 1953, Judge Stanley Fuld said that law reviews had "earned the real respect of the bench." Fuld, supra note 30 at 918 . Forty years later, they began to resemble the setup for one of comedian Rodney Dangerfield's punchlines. See Life, RODNEY DANGERFIELD, www.rodney.com [https://perma.cc/3ZFN-P5RY] (last visited July 13, 2020) ("Some chatty mob guys were the unintended inspiration for his signature catchphrase, 'I don't get no respect.' Rodney overheard them talking about respect-during one of his shows-and it was a Eureka moment for him."); see also David Hricik and Victoria S. Salzmann, Why There Should Be Fewer Articles Like This One: Law Professors Should Write More for Legal Decision-Makers and Less for Themselves, 38 SUFFOLK U. L. REV. 761, 778 (2005) ("Articles that have little or no perceived value to anyone but a few law professors will come to be read only by those few law professors.").

62 The idea that "perception is reality" entered our lexicon around this time, having been made famous by political strategist Lee Atwater during George H.W. Bush's 1988 presidential campaign. See Simon Kelner, Perception is reality: The facts won't matter in next year's general election, INDEPENDENT October 30, 2014 https://www.independent.co.uk/voices/comment/perception-is-realitythe-facts-wont-matter-in-next-years-general-election-9829132.html.

${ }^{63}$ Kaye, supra note 39, at 319; see also Kozinski, supra note 47, at 297 (Judge Kozinski described himself as a "big fan" of legal scholarship in his address, but also felt that, "[a]s best I can tell . . . some academics have almost a disdain for judicial interest in their work-or for whether and how their work will influence the outcome of cases."). But see Dolores K. Sloviter, In Praise of Law Reviews, 75 TEMPLE L. REV. 7, 7 (2002) (Judge Sloviter commended law reviews as "an expeditious vehicle by which to receive a comprehensive introduction to an unfamiliar field of law ... [and] an entrée into the most sophisticated thinking on the latest issues and trends").

${ }^{64}$ Harry T. Edwards, The Growing Disjunction Between Legal Education and the Legal Profession, 91 Mich. L. REV. 34, 36 (1992); see also United States v. \$639,558, 955 F.2d 712, 722 (D.C. Cir. 1992) (Silberman, J., concurring) ("[M]any of our law reviews are dominated by rather exotic offerings of increasingly out-of-touch faculty members."). Several likeminded scholars joined the fray as well. See e.g., Lasson, supra note 37, at 931 (calling lead articles "often overwhelming collections of minutiae, perhaps substantively relevant at some point in time to an individual practitioner or two way out in the hinterlands-and that almost entirely by chance") and Thomas E. Baker, Tyrannous Lex, 82 IowA L. REV. 689, 712 (1997) ("[L]aw reviews are to law what masturbation is to sex. They are a form of self-gratification for law professors and law students. They do not satisfy the needs of others."). 65 See Posner, supra note 57. 
crazy stuff is being published in law reviews nowadays,"66 but suggested that rather than "undergoing a serious decline ... production [of doctrinal scholarship had] shifted towards scholars at law schools of the second and third tier."67

This shift away from practical, doctrinal scholarship at the elite law schools and in their law reviews could help explain some of the shift away from the more prestigious, but more theoretical journals explored below, ${ }^{68}$ namely that the decline in the number and proportion of opinions citing to law reviews shown in Part I was driven in significant part by a decline in citations to the elite journals shown in Part II. ${ }^{99}$ Nevertheless, while the results of Part II show the gap in citation frequency has narrowed, there remains a striking preference among the judiciary for citing flagship journals from the elite law schools versus their less prestigious counterparts.

\section{PART II: THE ERODING BUT PERSISTENT CITATION ADVANTAGE OF ELITE LAW SCHOOL LAW REVIEWS}

The second part of this study represents my attempt to see how the proportion of opinions citing to flagship journals from several different law schools, selected and grouped according to their average U.S. News Ranking, changed in relation to each other as technology, legal scholarship, and academic legal publishing evolved over the last forty-five plus years. The data shows a pronounced citation advantage for journals from the elite schools, especially Harvard and Yale, as compared with those further down the hierarchy. This difference was especially striking during the 1970s, and despite some evidence of democratization, it is still clearly visible in the data for the most recent years of my study.

\footnotetext{
66 PosneR, supra note 59, at 101; see also Mary Ann Glendon, What's Wrong with Elite Law Schools, WALL ST. J. June 8, 1993, at A16 (in a letter to the Wall Street Journal, Harvard Law School Professor Mary Ann Glendon decried the "alarmingly widespread disdain for the useful forms of legal scholarship that systematize, refine, and incrementally extend knowledge about 'law'").

${ }^{67}$ Richard A. Posner, The Deprofessionalization of Legal Teaching and Scholarship, 91 MICH. L. REV. 1921, 1923 (1993). Judge Posner later noted that given "the increasingly able faculties of the lesser law schools, [t] he shift in legal doctrinal scholarship toward those faculties can hardly be considered a disaster for the profession." POSNER, supra note 59, at 95.

68 See infra text accompanying notes 84-88; see also Hricik \& Salzmann, supra note 61, at 780 n.3 ("We cannot ignore the fact that some of the most theoretical journals, those at the highest ranked schools, for example, are considered the most prestigious despite the lack of engaged scholarship.") and Richard A. Posner, Legal Scholarship Today, 115 HARV. L. REV. 1314, 1321 (2002) ("Traditional doctrinal scholarship is disvalued at the leading law schools. They want their faculties to engage in 'cutting edge' research and thus orient their scholarship toward, and seek their primary readership among, other scholars, not even limited to law professors, though they are the principal audience."). 69 See McClintock, supra note 32, at 688 ("In light of the heated debate between academia and the bar, the decline in [judicial citation of] legal scholarship seems at least in part attributable to the proliferation of impractical scholarship.").
} 


\section{JOURNAL SELECTION METHODOLOGY}

The U.S. News Best Law Schools Rankings, although controversial, 70 are the most visible embodiment of a hierarchy that existed in the legal academy long before they were first published. ${ }^{71}$ Consequently, I used the Rankings as the basis for categorizing and selecting the journals I included for comparison in this part of my study, which looks at judicial citations over the years 1970 through 2018. Other studies that have used the rankings found a strong correlation between a law school's rank and citations to its journals, ${ }^{72}$ especially among higher ranked schools. ${ }^{73}$

Harvard and Yale were selected as the most elite law schools for the study since they are the two most prestigious institutions in the country with the longest continually running student-edited law reviews. ${ }^{74}$ To choose the exemplar "Top-14"

\footnotetext{
70 See e.g., David A. Thomas, The Law School Rankings Are Harmful Deceptions: A Response to Those Who Praise the Rankings and Suggestions for a Better Approach to Evaluating Law Schools, 40 Hous. L. REV. 419, 423 (2003) ("[L]aw school rankings are so deeply and inherently flawed in concept that their publication does a profound disservice to persons trying to evaluate law schools.") and David Yamada, Same Old, Same Old: Law School Rankings and the Affirmation of Hierarchy, 31 SUFFOLK U. L. REV. 249, 261 ("[T] he obsession with prestige encouraged by these rankings nurtures a dynamic in which the sizzle counts for more than the steak.").

${ }^{71}$ See Olufunmilayo B. Arewa et al., Enduring Hierarchies in American Legal Education, 89 IND. L.J. 941, 941, 998 (2014) (evaluating law schools over the decades prior to the U.S. News Rankings through the modern era and finding "a consistent hierarchy of U.S. law schools from the 1930s to present"); see also Donna Fossum, Law Professors: A Profile of the Teaching Branch of the Legal Profession, 1980 AM. BAR FOUND. RES. J. 501, 514-15 (a study conducted during the 1975-76 academic year showed twenty elite law schools produced almost $60 \%$ of full-time law faculty, while graduates from five of those twenty schools [Harvard, Yale, Columbia, Michigan, and Chicago] accounted for just under a third of all full-time faculty).

72 Ronen Perry, Correlation versus Causality: Further Thoughts on the Law Review/Law School Liaison, 39 CONN. L. REV. 77, 83-84 (2006) (finding law school reputation drives differences in citation: "law school reputation is usually the cause whereas law review success is the effect."); see also Gregory Scott Crespi, Judicial and Law Review Citation Frequencies for Articles Published in Different "Tiers" of Law Journals: An Empirical Analysis, 44 SANTA ClaRA L. REV. 897, 897 (2004) ("[B]oth courts and scholars cite articles that are published in the three most prestigious law journals at much higher rates than they cite articles that appear in either mid-level or lower-tier law journals ... [and] courts virtually ignore altogether legal scholarship that appears in lower-tier law journals.").

${ }^{73}$ See Alfred L. Brophy, The Relationship between Law Review Citations and Law School Rankings, 39 CoNN. L. REV. 43, 49 (2006) (noting a correlation between peer assessment score and citations in law journals for schools in the top 100 using data from the U.S. News Rankings and the Washington \& Lee Journal Rankings); see also Ronen Perry, The Relative Value of American Law Reviews: Refinement and Implementation, 39 CoNN. L. REV. 1, 29-30 (2006) (finding a correlation between the overall rankings of law schools and their flagship journals, with a stronger correlation observed among higher-ranked institutions) and Ronen Perry, The Relative Value of American Law Reviews: A Critical Appraisal of Ranking Methods, 11 VA. J.L. \& TECH. 1, 35 (2006) (noting a correlation between citation frequency and higher law school rankings, especially among higher-ranked institutions).

${ }^{74}$ See supra notes $1-2$.
} 
law schools, I selected the three schools whose average ranking since 1987 fell closest to nine, the average of four and fourteen, while for tiers I and II, I chose twenty-five and seventy-five as my respective starting points for rankings. So for Tier I schools, I started with those ranked from 20 to 29 in 2018, recorded and averaged their ranks as far back as possible, and selected the three schools that came closest to twenty-five over that period. ${ }^{75}$ For Tier II, I had to expand my 2018 schools to those ranked 65-82 in order to find three schools that had never fallen outside of Tier II or its earlier equivalents, "3rd Tier" and "Quartile 2."76 Meanwhile, Tier III schools showed the greatest variability, forcing me to select the institutions that had fallen outside of Tier III or its equivalent the fewest number of years, irrespective of average. ${ }^{77}$ Lastly, the three Tier IV schools in my study were the only law schools that never fell outside of Tier IV or its equivalent. ${ }^{78}$

\section{JOURNAL TITLE SEARCH METHODOLOGY}

To generate my citation data for Part II, I created search strings comprising all of the possible ways I could imagine a court might cite to a particular journal title, and limited my results by year. ${ }^{79} \mathrm{I}$ would then scan my results and adjust my search as needed to remove as many false positives as possible. ${ }^{80} \mathrm{I}$ also made sure to account for any name changes to the journals included in my study, for example Notre Dame Law Review was known as Notre Dame Lawyer until 1982, while Emory Law Journal was originally published under the title Journal of Public Law. ${ }^{81} \mathrm{I}$ also excluded online companion journals such as the Harvard Law Review Forum from

\footnotetext{
75 As this project moved forward over the ensuing two years, the exemplar schools remained the same for all categories after factoring in the 2019 and 2020 U.S. News Rankings.

${ }^{76} \mathrm{I}$ also weighed ties in my rankings, so for example, if five law schools were each ranked 115, their weighted rank would each be 117. I believe this provides a more accurate benchmark for comparison between schools, as a difference as small as one point could see a school fall as many as twelve spots in the rankings.

77 There was a four-way tie between Cleveland State, Creighton, New York Law School, and the University of Missouri Kansas City, which I broke by choosing the school with the longest running journal.

78 U.S. News divided law schools into five tiers in the mid-1990s.

79 ("albany law review" OR "albany l. rev." OR "albany law rev." OR "alb. l. rev." OR "alb. l.r." OR "albany l.r.") \& DA(aft 12-31-2017 \& bef 01-01-2019).

80 This sometimes resulted in convoluted, but hopefully more accurate search strings: ("california law review" OR "california l. rev." OR "california law rev." OR "cal. l. rev." OR "cal. l.rev" OR "cal. l.r.") \& DA(aft 12-31-2017 \& bef 01-01-2019) and not("s. cal. l. rev.") and not ("so. cal. l. rev.") and not("southern california law review") and not("comm. reports") and not("law review commission") and not("l. rev. circuit") and not("law review circuit") and not("l. rev. cir.") and not("d. cal. l.r.") and not("dist. cal. l.r.") and not("district of cal. l.r.") and not("s. cal. l.r.") and not("so. cal. l.r.") and not("cd cal. l.r.") and not("22 cal. l.r.").

81 ("notre dame law review" OR "notre dame l. rev." OR "notre dame law rev." OR "notre dame law." OR "notre dame lawyer" OR "n.d. lawyer") \& DA(aft 12-31-2017 \& bef 01-01-2019) and not("notre dame l. rev. online") and not("notre dame law review online") and not("notre dame law school").
} 
my searches since I considered them separate publications. ${ }^{82}$ Lastly, since this study focuses on the proportion of opinions citing to law reviews as opposed to the overall number of citations, I ultimately combined the search strings for my journals into one query for each grouping, so if an opinion cited both the California Law Review and the Virginia Law Review, for example, it would not be counted twice.

\section{FINDINGS OF FAVORITISM}

I suspected the judiciary would cite to the Harvard Law Review, the Yale Law Journal, and the other high-ranked schools more often than those farther down the rankings, but I did not expect the difference to be as profound as the data reflected. These results suggest that perceived prestige of a law school is an important consideration when judges decide whether and to which law reviews they cite.

Harvard Law Review was cited in more opinions each year than any other journal from 1970 through 2018, with citations in more than twice the number of cases than its closest competitor, Yale Law Journal, most years between 1970 and 2010, with the gap narrowing somewhat over the past decade. Considered together, the proportion of opinions citing to these two journals out of the total number of reported opinions citing to at least one academic law review ${ }^{83}$ was highest at the beginning of the study period, reaching $34.4 \%$ in $1971 .{ }^{84}$ Meaning that, of all reported opinions in Part I that cited at least one academic legal periodical that year, more than one in three of those opinions cited either Harvard Law Review, Yale Law Journal, or both titles. This proportion decreased fairly steadily thereafter, falling below $25 \%$ in 1983 , below $20 \%$ in 1989 , and finally below $15 \%$ in 2000 , where it has remained since, reaching a low of $10.9 \%$ in 2007.

\footnotetext{
82 ("harvard law review" OR "harvard l. rev." OR "harvard law rev." OR "harv. l. rev." OR "harv. l.r." OR " review forum") and not("harv. l. rev. forum").

83 This was my combined search for opinions citing to the Harvard Law Review and Yale Law Journal for the year 2018: ("harvard law review" OR "harvard l. rev." OR "harvard law rev." OR "harv. l. rev." OR "harv. l.r." OR "harv lr" OR "harvard lr" OR "yale law journal" OR "yale l.j." OR "yale law jour." OR "yale law j." OR "yale l. jour.") \& DA(aft 12-31-2017 \& bef 01-01-2019) and not("harvard l. rev. forum") and not("harvard law review forum") and not("harv. l. rev. forum") and not("yale l.j. forum") and not("yale law journal forum") and not("yale l. jour. forum") and not("yale l.j. online") and not("yale law journal online") and not("yale l. jour. online") and not ("yale l.j. pocket part"). I entered the resulting number of reported opinions for each year into a spreadsheet, and divided that number by the total number of reported opinions from that year that cited at least one academic legal periodical (taken from Part I) and multiplied by 100 to arrive at my proportional percentage.

$84 \frac{895 \text { (\# of reported opinions citing } H L R \text { and } / \text { or } Y L J \text { ) }}{2,603 \text { (\# of reported opinions citing at least one academic legal periodical) }}=.3438 \times 100=34.4 \%$
} 
My findings largely mirror those of other studies that found courts cited journals from elite law schools far more often than their less prestigious counterparts. ${ }^{85}$ These studies almost invariably showed Harvard Law Review as the clear favorite among the judiciary. ${ }^{86}$ This was also true in the decades leading up to the $1970 \mathrm{~s} .{ }^{87}$

85 See, e.g., Saks et al., supra note 60, at 367 ("The rate of citation was about four times greater for articles in top-quintile law journals [versus other law reviews]."); McClintock, supra note 32, at 689; Crespi, supra note 72, at 909. Cf. Richard A. Mann, The Use of Legal Periodicals by Courts and Journals, 26 JURIMETRICS J. 400, 404 (1986) (this study shows less of an advantage for the elite schools, but only looked at journal articles from one year).

86 See, e.g., McClintock, supra note 32, at 689 (finding Harvard Law Review received nearly twice as many judicial citations as Yale Law Journal, and nearly three times as many citations as third place Columbia Law Review); Louis J. Sirico, Jr. \& Jeffrey B. Margulies, 34 UCLA L. REV. 131, 138, 142 (1986) (finding Harvard Law Review received more than twice as many citations as its nearest competitors during the 1971-1973 and 1981-1983 October Supreme Court Terms); Crespi, supra note 72, at 906 (finding 54 judicial citations to the 1996-1997 and 1997-1998 volumes of the Harvard Law Review, compared to 35 for the same volumes of the Yale Law Journal; however, Harvard Law Review received fewer law review citations during that period than both Yale Law Journal and Stanford Law Review). The lone exception that looked at judicial opinions was a study of citations to journal articles from 1978-1979 using Shepard's Law Review Citations from 1984 finding Yale Law Journal was the most-cited law review, while Harvard Law Review was fifth. Mann, supra note 85, at 404.

87 See Douglas B. Maggs, supra note 21, at 195 (even at this relatively early stage, when only 43 academic law reviews were being published, Harvard Law Review had already emerged as the leading journal with 53 total judicial citations, more than doubling the second-place Yale Law Journal with eighteen citations) and Newland, supra note 20, at 482 (in a study of Supreme Court opinions between the October Term, 1924 through the October Term of 1956, the Court cited Harvard Law Review 399 times, more than double the 194 citations to the second-place Yale Law Journal). 


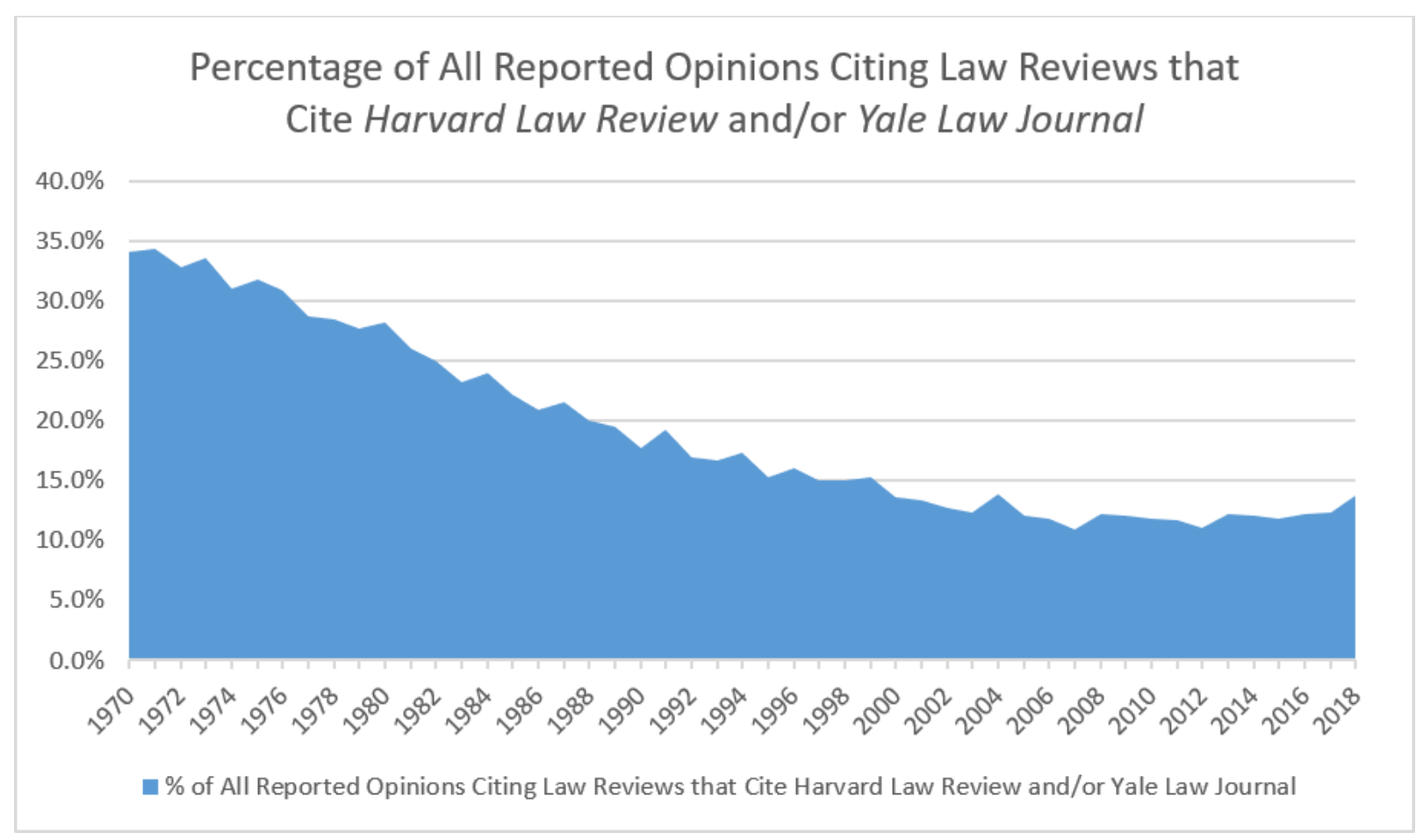

Law reviews from the study's three "Top 14" law schools, the University at California, Berkeley, the University of Pennsylvania, and the University of Virginia, were also heavily cited, although never as frequently as those from Harvard and Yale. As was the case with Harvard Law Review and Yale Law Journal, the proportion of opinions citing to these journals was highest during the 1970 s, reaching as high as $14.1 \%$ in 1970 , then declining below $10 \%$ beginning in 1984, below 5\% in both 2002 and 2003, then remaining between 5.1 and $6.6 \%$ through 2018. Additionally, the total proportion of opinions citing to at least one of the journals from these three law schools remained below the total proportion of opinions citing to either Harvard Law Review or Yale Law Journal, despite the fact that the Top 14 group included citations for three journals instead of two. 


\section{Percentage of All Reported Opinions Citing Law Reviews that Cite Top 14 \& Tier I Law Reviews}

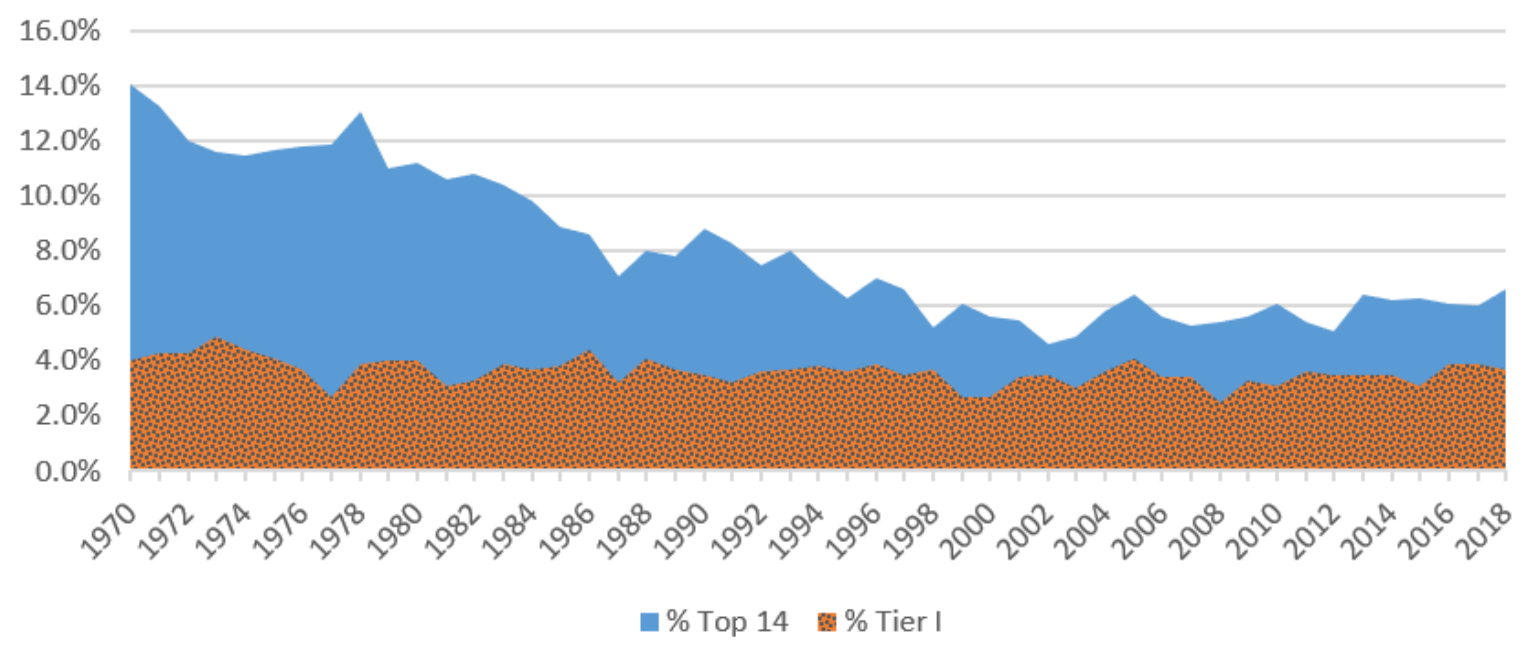

My exemplar Tier I law reviews were from Emory University School of Law, Notre Dame Law School, and the University of Iowa College of Law. Their combined citation rate was remarkably stable compared to the higher ranked schools above, reaching a high of $4.9 \%$ in 1973 , and averaging $3.6 \%$ over the period of study, with a standard deviation of .005, as compared to .026 for the three Top 14 journals, and .075 for the Harvard and Yale data.

My Tier II law schools were Loyola University of Chicago, the University of Kansas, and the University of Miami, while Albany, Drake University, and the University of Missouri at Kansas City represented Tier III. The data for the journals from the Tier II and Tier III law schools showed even less variability than the Tier I data, with a standard deviation of .003 for both datasets. Interestingly, the Tier III law reviews averaged slightly more citations than Tier II, with a mean of $1.6 \%$ versus $1.4 \%$. This indicates there may be less prestige variance between law schools in the eyes of the judiciary as one moves down the rankings into Tier II and Tier III institutions. ${ }^{88}$

\footnotetext{
88 See Perry, supra note 72, at 88 ("Law review success is determined to a great extent by school reputation ... [A]s we go down the school rankings ... the gaps between the schools' reputations get smaller. The differences in attractiveness between the respective law reviews must also become smaller.").
} 


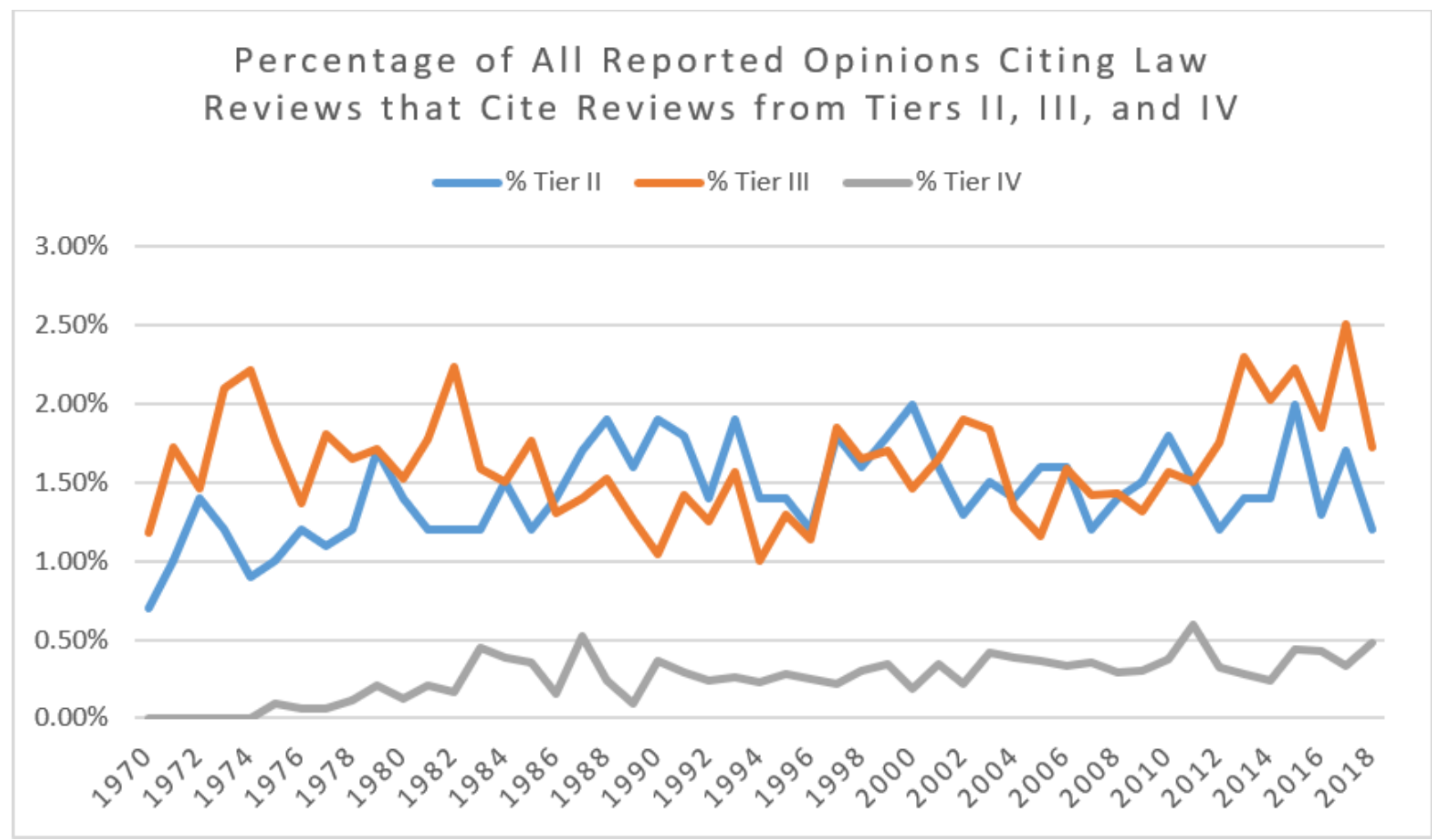

Finally, journals from the Tier IV law schools included in the study, New England, North Carolina Central University, and Texas Southern University, were cited least often, exceeding $0.5 \%$ only two times during the period of study. On average, this group of journals appeared in only $0.26 \%$ of the total number of reported opinions citing to academic legal periodicals between 1970 and 2018. The Tier IV dataset also had the lowest standard deviation among the journal groupings, .001.

Given these pronounced differences in citation rates between the different groupings of journals and the significant decrease in the proportion of citations to the elite journals over time, the balance of the article will be devoted to exploring potential reasons for the historic and continuing judicial preference for citing law reviews from the elite law schools and how changes in technology and academic publishing, have helped erode but not erase that advantage.

\section{REASONS JUDGES FAVOR ELITE LAW REVIEWS}

One factor that may drive up citations to elite law reviews is that journals from higher ranked schools tend to publish lengthier articles, and publish more articles per volume. ${ }^{89}$ This larger quantity of material gives their law reviews more

${ }^{89}$ Saks et al., supra note 60 , at 365. 
opportunities to be cited, ${ }^{90}$ even as they devote more space within their journals to more esoteric or nondoctrinal topics. ${ }^{91}$

In addition to publishing fewer and shorter articles, the extent to which law reviews at lower ranked schools focus on more localized issues will also impact their potential relevance to the judiciary. Devoting articles or even entire issues to surveys of state law, for instance, may increase the likelihood of being cited by courts within a law school's home state, ${ }^{92}$ but would substantially decrease the likelihood of being cited outside of it. 93

The prevalence of graduates of elite law schools among the judiciary, both among judges and their clerks ${ }^{94}$ could also help explain some of the favoritism they show for journals from higher ranked law schools. ${ }^{95}$ At least one study suggested that judges are more likely to cite journals from their alma mater, ${ }^{96}$ which makes sense at least intuitively given the attachment that many of us feel to the educational

90 James Leonard, Seein' the Cites: A Guided Tour of Citation Patterns in Recent American Law Review Articles, 34 ST. LOUIS U. L.J. 181, 193 (1990) ("Logically, all other things being equal, law reviews with more pages will be cited more frequently than less lengthy titles simple because there is more material to cite.").

91 See supra notes 59-66 and accompanying text.

92 Deborah J. Merritt \& Melanie Putnam, Judges and Scholars: Do Courts and Scholarly Journals Cite the Same Law Review Articles?, 71 CHI.-KENT L. REV. 871, 885 (1996); see also Noteboom \& Walker, supra note 10, at 448 (the majority of judges and attorneys responding to a 1966 survey "felt quite strongly that there should be increased emphasis on state law and other matters of local concern").

${ }_{93}$ See Mann, supra note 85, at 415 (finding that journals whose scholarship focused on national issues had a higher rate of citation versus localized journals).

94 Jason Iuliano \& Avery Stewart, The New Diversity Crisis in the Federal Judiciary, 84 TenN. L. REV. 247, 279-98 (2016) (finding graduates from elite law schools, and Harvard in particular, are over-represented across the federal judiciary, with this discrepancy having increased significantly over the course of the twentieth century. The authors found a similar trend among those selected for federal clerkships, with graduates from the top five schools representing $24 \%$ of the total across the country. This advantage was even more pronounced among U.S. Supreme Court clerks, with graduates of Harvard and Yale law schools representing 24.8 and 19\% of all clerks, respectively, between 1950 and 2015).

95 See Sirico \& Margulies, supra note 86, at 133-34 ("[J]udicial clerks hailing largely from elite schools may tend to cite the publications of their respective alma maters in their memoranda and opinion drafts.").

96 See e.g., Richard G. Kopf, Do Judges Read the Review - A Citation-Counting Study of the Nebraska Law Review and the Nebraska Supreme Court, 76 NEB. L. REV. 708 (1997) (finding judges who graduated from the University of Nebraska accounted for $40 \%$ of the Nebraska Supreme Court's opinions citing to the Nebraska Law Review, while graduates of Creighton University School of Law were less likely to cite it, accounting for $29 \%$ of the opinions citing the Nebraska Law Review. Meanwhile, judges who graduated from Creighton Law School were "nearly twice as likely (15 to 8) to cite the Creighton Law Review compared with their judicial colleagues who graduated from the University of Nebraska"). 
institutions we attended. ${ }^{97}$ So not only are they likely to favor the law review they may have worked for during law school, as graduates of elite law schools themselves, they may also internalize the same value judgments about lower ranked law schools that motivate the hiring decisions of their judges. ${ }^{98} \mathrm{In}$ fact, it is this longstanding elitism that is likely the most impactful factor driving citations disproportionately in favor of law reviews from elite law schools, both in the academy and among the bench and bar. ${ }^{99}$

Indeed, the late Justice Antonin Scalia admitted this bias in his selection of law clerks, ${ }^{100}$ a bias that seems at least tacitly shared by many of his Supreme Court colleagues. ${ }^{101}$ It does not take a great inferential leap to suggest this elitism is also present when judges decide whether or not to cite to a particular article when writing an opinion. ${ }^{102}$

97 See e.g., Scott Gaier, Alumni Satisfaction with Their Undergraduate Academic Experience and the Impact on Alumni Giving and Participation, 5 INT'L J. EDUC. ADVANCEMENT 283-84 (2005)

(reporting significant increases in both philanthropy and participation among alumni based on their reported level of satisfaction with their undergraduate academic experiences) and Fred Mael \& Blake E. Ashforth, Alumni and their alma mater: A partial test of the reformulated model of organizational identification, 13 J. ORG. BEHAV. 102, 112-17 (1992) (noting that organizational prestige can enhance alumni attachment to their institution: "[H]ighly regarded schools are often steeped in lore and traditions which glorify their uniqueness and excellence.").

98 William D. Henderson \& Rachel M. Zahorsky, The Pedigree Problem: Are Law School Ties Choking the Profession?, ABA J. (July 1, 2012 10:20 AM),

https://www.abajournal.com/magazine/article/the_pedigree_problem_are_law_school_ties_choking_th e_profession [https://perma.cc/W9NJ-QN9C] ("Students vetted through the rankings-era admissions process are now mid-career professionals who ... strongly adhere to law school brands"); see also infra text accompanying notes 100-102.

${ }_{99}$ Merritt \& Putnam, supra note 92, at 890 (citing Fred R. Shapiro, The Most-Cited Law Review Articles Revisited, 71 CHI.-KENT L. REV. 751 (1996)) (study compared most-cited articles from judicial opinions over the years 1989 - 1991 with the results of another study of most-cited articles appearing in legal periodicals over the same time period, finding "judges resemble academic authors in drawing their most heavily cited articles disproportionately from a few elite journals . . . [however, they] appear more willing to reach beyond the most prestigious journals in citing certain articles repeatedly.").

100 Adam Liptak, On the Bench and Off, the Eminently Quotable Justice Scalia, N.Y. TIMEs (May 11, 2009) https://www.nytimes.com/2009/05/12/us/12bar.html [https://perma.cc/GJ3C-7HTU] (while explaining to a law student from American University why she is unlikely to be selected for a U.S. Supreme Court Clerkship, Justice Scalia told her, "By and large, I'm going to be picking from the law schools that basically are the hardest to get into. They admit the best and brightest, and they may not teach very well, but you can't make a sow's ear out of a silk purse. If they come in the best and brightest, they're probably going to leave the best and brightest, O.K.?").

${ }^{101}$ Id. ("Over the last six years, the justices have hired about 220 law clerks. Almost half went to Harvard or Yale. Chicago, Stanford, Virginia, and Columbia collectively accounted for 50 others."). 102 Lee Petherbridge \& David L. Schwartz, An Empirical Assessment of the Supreme Court's Use of Legal Scholarship, 106 Nw. U. L. REV. at 1020 ("Our results are consistent with the possibility that the [U.S. Supreme] Court is taking prestige of some sort when it uses legal scholarship. It might take the prestige of the author ... [or] of the publishing law review or the institution affiliated with the law review."). 
This bias is certainly present in the academy as well, where a disproportionate number of professors come from the most elite law schools, ${ }^{103}$ and tenure decisions can hinge on placement in top law reviews. ${ }^{104}$ And while elitism is perhaps most visible among the practicing bar during the hiring process, ${ }^{105}$ as with the judiciary, I find it unlikely that these biases do not intrude once attorneys remove their "hiring caps" to work on research and writing. This makes them more likely to cite to elite journals in their briefs, which the court may, in turn, incorporate into its own analysis. ${ }^{106}$

It is also possible that these differences in citation frequency reflect actual qualitative differences between articles published in the elite schools' journals versus those from less prestigious schools. It would follow that the "best and brightest" students, ${ }^{107}$ whose journals attract the most renowned scholars, ${ }^{108}$ would be in a position to produce the highest quality scholarship, but this is also difficult

103 See Howard A. Glickstein, Law Schools: Where The Elite Meet To Teach, 10 Nova L.J. 541, 542-43 (citing LAW SCHOOLS AND PROFESSIONAL EDUCATION: REPORT AND RECOMMENDATIONS OF THE Special Committee for a Study of Legal EduCATion of the AMERICAN BAR Association (1980)) ("59\% of all law school teachers possessed J.D. degrees from one of the 20 top 'producer' schools, while almost $90 \%$ of tenure track faculty at the 20 'producer' schools held the J.D. from those same schools. Nearly a third of full-time law teachers received their J.D. degrees from one of five law schools (Harvard, Yale, Columbia, Michigan and Chicago).").

104 See, e.g., Alfred L. Brophy, The Signaling Value of Law Reviews: An Exploration of Citations and Prestige, 36 FLA. ST. U. L. REV. 229, 230 (2009) (describing the practice of "trading up" where faculty rescind a previously accepted journal placement when they receive an offer from a more prestigious journal, adding "for purposes of job placement and pay increases, it is not unreasonable to assume that articles placed in more prominent journals are more useful, as a general matter, than articles placed in less prominent journals. In fact, some schools are reputed to pay bonuses for articles placed in highly regarded journals. This is because evaluators use journal placement as a proxy for article quality."). See also Lisa Anderson, Law Journals Attack "Shopping" of Manuscripts, N.Y. TIMES, July 12, 1995, at B6, https://www.nytimes.com/1995/07/12/us/law-journals-attack-shopping-ofmanuscripts.html [https://perma.cc/6LY9-MQQ7]. ("Law professors know that to move into their profession's tenured ranks their work must be published in law journals, the more prestigious the better.").

${ }^{105}$ Henderson \& Zahorsky, supra note 98 ("Snobbism and elitism are the last socially acceptable prejudices . . . largely rooted in vanity and identity, ... [t] his near obsession with pedigree is not only paralyzing to the career prospects of individual lawyers; it is damaging to the entire profession."). 106 See Sirico \& Margulies, supra note 86, at 133 ("Attorneys may rely primarily on supportive articles in elite journals, because they hope that a journal's name will increase an article's persuasive power.") and William H. Manz, Citations in Supreme Court Opinions and Briefs: A Comparative Study, 94 LAW LIBR. J. 267, 274 (2002) (comparing citations contained in briefs submitted to the Supreme Court during the October 1996 Term with citations appearing in the Court's opinions and finding $9.5 \%$ of legal periodicals in the winning side's briefs were also cited by the Court, while $7 \%$ of those from losing brief were cited).

107 See Liptak, supra note 100.

108 See Jason P. Nance \& Dylan Steinberg, The Law Review Article Selection Process: Results from a National Study, 71 ALB. L. REV. 565, 589 (2008) (explaining student editors' consideration of author reputation in making editorial decisions to secure a competitive advantage for their journal). 
to measure. ${ }^{109} \mathrm{I}$ also find it unlikely that qualitative differences alone can explain the stark discrepancies in citation frequency reflected in the data. However, the fact that these hierarchical differences in citation frequency have decreased suggests that judges have become more focused on the content of a journal rather than the name on the cover, or that the qualitative gap between the journals has narrowed over time. ${ }^{110}$ More likely, it is a culmination of many factors, including those explored below that have driven these changes.

\section{MIND THE (NARROWING) GAP: REASONS THE ELITE LAW REVIEW CITATION ADVANTAGE HAS ERODED}

Some of the factors behind the overall decline in judicial citation of law reviews have also helped to level a playing field that elitism and tradition had tilted steeply in favor of journals from the most prestigious law schools. Changes to the process of locating and retrieving legal information driven by technology and the expansion and evolution of scholarship into new areas driven by the elite law schools helped narrow the citation gap between law reviews from the lower and higher-ranked law schools. Additionally, the sharp increase in the number of legal periodicals being published over the period of study undoubtedly diluted the citation advantage of the elite journals, driving down the relative frequency with which they were cited.

\section{TECHNOLOGY: THE CONTINUING EFFECT OF CALR}

When Lexis and Westlaw began adding full-text, searchable law review articles to their databases in 1982, it marked the beginning of a slow but wholesale change in the way that legal researchers would access journal articles. Since both databases only added select titles to their databases, they initially increased discoverability of only those (mostly prominent) journals, which likely exacerbated the citation gap between the different institutions. ${ }^{111}$ However, as they expanded their selection of periodicals, Lexis and Westlaw, along with HeinOnline ${ }^{112}$ and LegalTrac, ${ }^{113}$

\footnotetext{
${ }^{109}$ But see Crespi, supra note 72, at 917 ("[B]ecause of the filtering and sorting effects of the competitive editorial process . . . tier-specific differences in citation frequencies . . . might reflect with some accuracy the relative quality of the articles themselves.").

110 See PoSNER, supra note 59, at 95 ("No area of practice or doctrine is beyond the intellectual competence of the increasingly able faculties of the lesser law schools.").

111 See COHEN ET AL., supra note 36, at 376; see also Hood, supra note 35, at 112 (noting as of 1987 that Lexis offered full-text coverage of "over thirty" journals dating back to 1982, while Westlaw provided incomplete coverage for "many more" journals than Lexis over the same time period, but complete coverage for "top" legal journals only).

112 HeinOnline established its online presence in May 2000. Joe Gerken, The Invention of HeinOnline, 18 AALL SPECTRUM 17 (Feb. 2014), https://heinonline.org/HeinDocs/Gerken.pdf [https://perma.cc/7JXW-ALDE].

${ }^{113}$ LegalTrac was initially offered on disc before moving online. See Scott L. Rawnsley, 6 LEGAL REFERENCE SERVICES Q. 169, 174 (1986).
} 
democratized legal research by facilitating discovery and access to all legal periodicals. ${ }^{114}$

Once legal researchers began using these services, where search results are typically ranked by relevance and articles can be accessed with the click of a button, they would no longer need to pull a physical volume from a shelf. ${ }^{115}$ In theory, this should lead to a greater tendency for judges and clerks to consult all legal periodicals rather than just the most prestigious publications since online researchers are presumably "less likely to focus on the source and instead . . . focus more directly on the content of the material."116

However, these technological changes may not have equated to a corresponding increase in citations to all legal periodicals, as judges who consult even the most useful article may nevertheless choose not to cite it. ${ }^{117}$ Additionally, the fact that judicial citations to the higher ranked law reviews began to decrease before the introduction and widespread adoption of full-text electronic access to legal periodicals indicates other factors have also contributed to this change.

\section{THE IVY LEAGUE IVORY TOWER}

The shift towards impractical scholarship at the more elite law schools beginning in the 1970 s and $80 \mathrm{~s}$, as discussed above, likely also contributed to this trend. ${ }^{118}$ Quite simply, as elite law reviews published increasingly esoteric articles, frustrated judges were less likely to consult them. ${ }^{119}$ Meanwhile, the fact that concurrent data

\footnotetext{
114 See Hibbitts, supra note 36 , at 658-59.

115 Camille Broussard, Teaching with Technology: Is the Pedagogical Fulcrum Shifting?, 53 N.Y.L. ScH. L. REV. 903, 910 (2009) ("Hypertext linking gives the reader the ability to move around in a digitized textual document by opening a limitless array of additional links to other digitized material.").

116 Margolis, supra note 42, at 934 (asserting that online research creates a blurring effect in regards to types of authority consulted by the legal researcher). I suspect this point is also valid when applied to different legal periodicals. But see Perry, supra note 73, at 32 (suggesting that, due to the prohibitive volume of material available, scholars "may base their reading strategies on law schools' reputation ... assuming that journals of more prestigious schools will always publish better papers").

117 See Paul L. Caron, The Long Tail of Legal Scholarship, 116 YALE L.J. PockET PART 38, 41 (2006) ("Citations reflect one particular end-use of an article; they do not measure how many times an article is read but not cited."); see also Kaye, supra note 39, at 313 n.2 ("I read a great many more law review articles than I cite in my opinions.") and Margolis, supra note 42, at 917 ("New legal researchers are taught that [secondary] sources are useful for gaining general background about the law, but should rarely be cited directly in support of legal analysis.").

118 See supra notes 59-66 and accompanying text.

119 See Adam Liptak, When Rendering Decisions, Judges Are Finding Law Reviews Irrelevant, N.Y Times, Mar. 19, 2007, at A8 https://www.nytimes.com/2007/03/19/us/19bar.html [https://perma.cc/P3DJ-GCBD] (quoting Second Circuit Court of Appeals Judge Dennis Jacobs, "I haven't opened up a law review in years ... No one speaks of them. No one relies on them."); see also McClintock, supra note 32, at 688 (speculating that one reason for the decline in judicial citations to law reviews is that judges no longer read them).
} 
for the exemplar journals from Tiers I-IV did not show a similar decrease as their more prestigious counterparts provides further evidence that they retained their relative value to the judiciary throughout the period of study. This is especially notable considering the downward pressure exerted on the proportion of citations to all periodicals as a result of the increasing number of new journals established from the 1970s forward.

\section{DILUTION}

It is this final factor that I believe was most impactful in narrowing the hierarchical gap between the different tiers of law reviews, the exponential increase in the number of journals publishing legal content from the 1970s to present. These additional titles and the corresponding increase in articles these new journals published diluted the citation advantage enjoyed by the higher ranked law school journals through their sheer volume. ${ }^{120}$

For example, in 1970, the Current Index to Legal Periodicals indexed 132 journals; by 2010 , that number had increased to $616,{ }^{121}$ and today it stands at over $650,{ }^{122}$ an increase of $392 \%$. Researchers today can search 944 titles in Lexis Advance's Law Reviews \& Journals database ${ }^{123}$ and 1,040 titles on Westlaw Edge. ${ }^{124}$ And while perhaps not as ubiquitous as Lexis and Westlaw, LegalTrac indexes more than 1,200 different legal periodicals, ${ }^{125}$ while HeinOnline currently provides subscribers with full-text access to over 2,800 different titles through their Law Journal Library. ${ }^{126}$ So not only are there far more law journals today than in the past, articles are more easily discoverable for researchers than ever before.

\footnotetext{
${ }^{120}$ Pierce \& Reuben, supra note 32, at 1195 (authors labeled this concept "diffusion"); see also Robert M. Lawless \& Ira David, The General Role Played by Specialty Law Journals: Empirical Evidence from Bankruptcy Scholarship, 80 AM. BANKR. L. J. 523 (2006) (in a study of legal scholarship in the field of bankruptcy, authors' findings "suggest that specialty journals play a different role than do the general law reviews, perhaps filling some of the lamented disjunction between the academy and the practicing legal community, including judges").

${ }^{121}$ Alena Wolotira, From a Trickle to a Flood: A Case Study of the Current Index to Legal Periodicals to Examine the Swell of American Law Journals Published in the Last Fifty Years, 31 LEGAL REFERENCE SERVICES Q. 150, 157 (2012) (showing an increase in the number of journals indexed by Current Index to Legal Periodicals from 90 in 1960 to 616 in 2010).

122 CILP Journals, supra note 25.

${ }^{123}$ Email to Celine Murphy, Lexis Practice Area Consultant, (Dec. 12, 2019 9:45 AM) (on file with author).

124 Secondary Sources, WestLaW EDGE, https://www.westlaw.com/Browse/Home/SecondarySources/SecondarySourcesLibrary?transitionType $=$ Default\&contextData $=($ sc.Default $) \& V R=3.0 \& R S=$ cblt1.0 (last visited July 7, 2020) To obtain my total, I filtered my results by Publication Type to "Law Reviews \& Journals" only. ${ }_{125}$ Gale OneFile: LegalTrac, GALE, https://www.gale.com/c/onefile-legaltrac [https://perma.cc/ULR9PM2H] (last visited July 7, 2020).

${ }^{126}$ Law Journal Library, HEINONLINE, https://home.heinonline.org/content/law-journal-library/ [https://perma.cc/C5DK-74CW] (last visited July 7, 2020).
} 


\section{CONCLUSION}

Given these changes and others sure to come over the decades ahead, it will be interesting to see what the future holds in store for the student-edited law review. As Judge Judith Kaye remarked over thirty years ago, "In time, the judiciary's prejudice against citing law reviews gave way. More precisely, it collapsed and vanished without a trace." 127 And while the contemporaneous data in his study support Judge Kaye's assertion, the data also shows that another prejudice has endured, namely a strong bias among the courts in favor of citing law reviews from the most prestigious law schools.

Additionally, while the judiciary's prejudice against citing law reviews may have vanished for a time, it seems to have come back into fashion, considering the overall citation data from the last forty years and some of the criticisms from the bench over that time. Of course, the law review as an institution has always had its detractors, ${ }^{128}$ but it has also endured for over a century and continues to evolve. In fact, a study of Supreme Court opinions through 2010 found that Chief Justice Roberts used legal scholarship in $23 \%$ of his opinions. ${ }^{129}$ Despite the Chief Justice's well-known reservations about the practical value of law reviews, ${ }^{130}$ this proportion was roughly in line with his colleagues. ${ }^{131}$ So perhaps there is some reason for optimism on behalf of law reviews after all.

It remains to be seen if the recent increases in the proportion and quantity of opinions citing law reviews in this study portend greater reliance on legal scholarship by the courts in the coming years. Likewise, it will be interesting to see if the factors discussed above in Part II and others we have yet to consider continue to chip away at the citation advantage of the elite law reviews. In either case, only time, and future inquiry, ${ }^{132}$ will tell.

\section{ACKNOWLEDGEMENTS}

The author would like to thank Kathleen Lynch for her invaluable research assistance during her practicum at the Charles B. Sears Law Library, as well as our Lexis Representative Celine Murphy for her helpful suggestions in crafting my searches. I am also indebted to my colleagues Beth Adelman, Theo Belniak, and Kate Cunningham for their proofreading assistance. Any mistakes are my own.

\footnotetext{
127 Kaye, supra note 39 , at 316.

128 See, e.g., Fred Rodell, Goodbye to Law Reviews, 23 VA. L. REv. 38, 38 (1936) ("There are two things wrong with almost all legal writing. One is its style. The other is its content.").

${ }^{129}$ Petherbridge \& Schwartz, supra note 102, at 1025.

130 See supra text accompanying note 3.

131 Petherbridge \& Schwartz, supra note 102, at 1025.

132 See id. at 1020 ("[E]mpirical work is iterative, and future work should be performed to test, substantiate, and build on our results.").
} 


\section{APPENDIX A}

My initial search included all academic journal citations possible before receiving a "502 Gateway Error" message from Lexis, which excluded those titles receiving fewer than seven citations during the period of study, 1945-2018. ${ }^{133}$

133 ("law review" OR "law journal" OR "l. rev." OR "law rev." OR "l.j." OR "l. jour." OR "jour. l." OR "journal of law" OR "j.l. pub." OR "j. urb. l." OR "j.l. tech." OR "j. crim. l." OR "j. const. l." OR "j. corp. l." OR "j. int'l. l." OR "j. int'l comp. l." OR "j. juv. l." OR "j. envtl. l." OR "j. fam. l." OR "j. on legis." OR "l. pol'y" OR "j. pub. l." OR "wash. u.l.q." OR "cornell l.q." OR "notre dame law." OR "n.y.u. l.q." OR "w.va. l.q." OR "l. soc. change" OR "am. crim. l.q." OR "ill. l. forum" OR "rev. col. abog." OR "j. pol. econ." OR "am. j. juris." OR "crim. l.q." OR "l.sch. j." OR "evtl. aff." OR "miami l.q." OR "iowa l. bull." OR "ind. legal forum" OR "marshall l.q." OR "harv. l. sch. bull." OR "duke bar" OR " $n . y . l$. forum" OR "urb. l. ann." OR "j. legal educ." OR "n.y. law forum" OR "neb. l. bull." OR "tul. tax. inst." OR "so. l.q." OR "ky. st. l. forum" OR "race rel. rep." OR "inst. on est." OR "u. ill. l.f." OR "j. small emerging bus. l." OR "n.y.l.f." OR "qlr" OR "clara law." OR "widener l. symp. j." OR "j. prac. proc." OR "crim. just. j." OR "law soc. ord." OR "j. art tech." OR "surv. int'l comp. l." OR "j. corp. fin. comm. l." OR "j. bus. entrepreneurship" OR "j. eur. l." OR "j. complex litig." OR "j. soc. just." OR "transnat'l l. contemp. probs." OR "j.l. comm." OR "u. bus. rev." OR "j. sports l." OR "l. soc. just." OR "j.l. religion" OR "j.l. family" OR "appalachian j.l." OR "j. health biomedical" OR "j. civ. rts." OR "l. psychol. rev." OR "j. conflict resol." OR "hall cir. rev." OR "j. bus. sec. l." OR "hum. rts. j." OR "fla. tax rev." OR "yale j. on reg." OR "j.l. sci. tech." OR "sports law.j." OR "j. int'l bus." OR "ecol. l.q." OR "j. global legal stud." OR "rev. banking fin." OR "l. bus. rev." OR "j. oil gas energy l." OR "crim. just. j." OR "j. med. l." OR "j.l. liberty" OR "j. affordable housing" OR "n.c. banking inst." OR "j. tech. intell." OR "j. gender race" OR "j.l. fam." OR "j. bus. tech. l." OR "cath. law." OR "u. mass. l. rev." OR "j. health pol'y" OR "j. pub. int. l." OR "j. race l." OR "j. gender soc. pol'y" OR "animal l." OR "j. ent. tech." OR "const. comment" OR "health matrix" OR "j.l. feminism" OR "j. women l." OR "contemp. legal issues" OR "sup. ct. rev." OR "j. app. prac." OR "temple l.q." OR "j.l. educ." OR "bill rts. j." OR "va. tax rev." OR "j. soc. pol'y l." OR "j.l. reform" OR "chi. legalf." OR "rev. l. pol." OR "seton hall legis. j." OR "rev. litig." OR "j. disp. resol." OR "j.l. ethics" OR "rev. l. soc." OR "j.l. bus." OR "surv. am. l." OR "law pol'y int'l" OR "law contemp. probs." OR "j. legal prof." OR "j. legal stud." OR "j.l. soc." OR "j.l. econ." OR "j. intell. prop." OR "j. empirical legal stud." OR "health l. pol'y" OR "j. air l." OR "j. legis." OR "envtl. l. pol'y rev." OR "j. computer info. l." OR "j. bus. l." OR "const. l.q." OR "geo. j. legal ethics" OR "j. corp. fin. l." OR "j. land use envtl." OR "emp. pol'y j." OR "bankr. dev. j." OR "l. pol'y f." OR "j. agric. l." OR "j. health care l." OR "j.l. arts" OR "j. transnat'l l." OR "j.l. soc. probs." OR "j.l. gender" OR "j. corp. fin. com. l." OR "j. sci. tech. l." OR "j. gender l." OR "j. lab. emp. l." OR "j. emp. lab. l." OR "akron tax j." OR "law ineq." OR "j. trial advoc." OR "rev. int'l arb." OR "ark. l. notes" OR "rev. jur. u.p.r." OR "ecology l.q." OR "crim. civ. confinement" OR "nat. resources j." OR "j. urb. contemp. l." OR "j. on disp. resol." OR "j. contemp. l." OR "j.l. health" OR "j. int'l law" OR "rev. der. p.r." OR "sports ent. l." OR "resources envtl. l." OR "annals health l." OR "l. fam. stud." OR "j. comp. int'l l." OR "j. hum. rts." OR "ann. rev. banking l." OR "j. trial app. advoc." OR "lab. rel. rev." OR "j.l. fam." OR "j. high tech. l." OR "j.l. com." OR "balt. l.f." OR "j.c.r. c.l." OR "commlaw" OR "cap. def. j." OR "transnat'l law." OR "l. tech. j." OR "inst. on fed. tax'n" OR "rutgers l. rec." OR "soc. serv. rev." OR "f. on c.l. c.r." OR "j. civil rts." OR "legal rts. j." OR "j.l. pol." OR "j. for soc. just." OR "j. afr-am. l." OR "civ. rts. econ." OR "chi.-kent" OR "j. child fam. advoc." OR "j. s. legal hist." OR "j.c.r. econ.") \& DA (aft 12-31-2017 \& bef 01-01-2019) and not ("n.y.l.j.") and not ("comm. reports") and not ("law review commission") and not ("law rev. comm") and not ("law rev. commn") and not ("law rev. com.") and not ("tax law rev.") and not ("admin. l. rev." and not ("mil. l. rev.") and not ("mass. l. rev.") and not ("bank. inst. l. rev.") and not ("am. j. int'l l.") and not ("am. j. comp. l.") and not ("a.f. l. rev.") and not ("fed. cts. l. rev.") and not ("am. l. rev.") and not ("mod. l. rev.") and not ("notre dame law school"). 
Due to the high number of false positives I received by including "l.j." in my initial search, I decided to run a second search and exclude the results from my initial totals, while ensuring all possible citation variations to academic law journals would not be subtracted. ${ }^{134}$ This search accounted for all academic journals with the

134 ("l.j.") \& DA(aft 12-31-2010 \& bef 01-01-2012) and not ("l. rev.") and not ("yale l.j.") and not ("georgetown l.j.") and not ("hastings l.j.") and not ("duke l.j.") and not ("alb. l.j.") and not ("albany l.j.") and not ("cornell l.j.") and not ("emory l.j.") and not ("ind. l.j.") and not ("indiana l.j.") and not ("rutgers l.j.") and not ("widener l.j.") and not ("geo. l.j.") and not ("n.c. cent. l.j.") and not ("miss. l.j.") and not ("ill. l.j.") and not ("tex. l.j.") and not ("texas l.j.") and not ("ky. l.j.") and not ("hast. l.j.") and not ("tech.l.j.") and not ("depaul bus.") and not ("berkeley bus. l.j.") and not ("hastings bus. l.j.") and not ("duq. bus. l.j.") and not ("rutgers bus. l.j.") and not ("entrepen. bus. l.j.") and not ("davis bus. l.j.") and not ("vand. l.j.") and not ("u.p.r. bus. l.j.") and not ("rico bus. l.j.") and not ("nevada l.j.") and not ("chi. l.j.") and not ("kentucky l.j.") and not ("mary's l.j.") and not ("marys l.j.") and not ("ohio l.j.") and not ("nev. l.j.") and not ("denver l.j.") and not ("brandeis l.j.") and not ("basin l.j.") and not ("hall l.j.") and not ("thomas l.j.") and not ("hamline l.j.") and not ("willamette l.j.") and not ("rock l.j.") and not ("ualr l.j.") and not ("washburn l.j.") and not ("wash. l.j.") and not ("u. ark. l.j.") and not ("hasting l.j.") and not ("tulsa l.j.") and not ("wyoming l.j.") and not ("blackletter l.j.") and not ("coastal l.j.") and not ("wyo. l.j.") and not ("nova l.j.") and not ("denv. l.j.") and not ("den. l.j.") and not ("louis l.j.") and not ("howard l.j.") and not ("how. l.j.") and not ("cam. l.j.") and not ("camden l.j.") and not ("u.a.l.r. l.j.") and not ("marshall l.j.") and not ("state l.j.") and not ("u. l.j.") and not ("univ. l.j.") and not ("det. l.j.") and not ("envtl. l.j.") and not ("envt. l.j.") and not ("env. l.j.") and not ("st. l.j.") and not ("const. l.j.") and not ("world l.j.") and not ("admin l.j. am.") and not ("pac. l.j.") and not ("pacific l.j.") and not ("sci. l.j.") and not ("l.j. sci.") and not ("y.l.j.") and not ("md. l.j.") and not ("int'l l.j.") and not ("intl. l.j.") and not ("international l.j.") and not ("interest l.j.") and not ("int. l.j.") and not ("hofstra lab. l.j.") and not ("comp. lab. l.j.") and not ("educ. l.j.") and not ("prop. l.j.") and not ("can.-u.s. l.j.") and not ("ent. l.j.") and not ("entertainment l.j.") and not ("conn. ins. l.j.") and not ("elder l.j.") and not ("fed. comm. l.j.") and not ("urb. l.j.") and not ("urban l.j.") and not ("women's l.j.") and not ("rights l.j.") and not ("rts. l.j.") and not ("rits. l.j.") and not ("immigr. l.j.") and not ("immigration l.j.") and not ("gaming l.j.") and not ("emp. l.j.") and not ("empl. l.j.") and not ("bus. com. l.j.") and not ("tax l.j.") and not ("sports l.j.") and not ("mar. l.j.") and not ("maritime l.j.") and not ("con. l.j.") and not ("black l.j.") and not ("dev. l.j.") and not ("resol. l.j.") and not ("quinnipiac health l.j.") and not ("quinnipiac prob. l.j.") and not ("quinnipiac probate l.j.") and not ("hofstra labor l.j.") and not ("conn. prob. l.j.") and not ("detroit l.j.") and not ("conn. probate l.j.") and not ("interdisc. l.j.") and not ("interdis. l.j.") and not ("interdisciplinary l.j.") and not ("transp. l.j.") and not ("trans. l.j.") and not ("commercial l.j.") and not ("asian am. l.j.") and not ("asian l.j.") and not ("actec l.j.") and not ("tch. l.j.") and not ("reserve l.j.") and not ("indian l.j.") and not ("computer l.j.") and not ("drug l.j.") and not ("cosm. l.j.") and not ("raza l.j.") and not ("ohio s. l.j.") and not ("dame l.j.") and not ("loy. l.j.") and not ("southwestern l.j.") and not ("u. chicago l.j.") and not ("mich. l.j.") and not ("will. l.j.") and not ("geor. l.j.") and not ("harvard l.j.") and not ("wis. internat. l.j.") and not ("tex. internat. l.j.") and not ("envt'l l.j.") and not ("o.s. l.j.") and not ("tul. l.j.") and not ("fordham internat. l.j.") and not ("ethnic anc. l.j.") and not ("software l.j.") and not (s.w. l.j.") and not ("sw. l.j.") and not ("comp. l.j.") and not ("u.s.-mex. l.j.") and not ("poverty l.j.") and not ("phoenix l.j.") and not ("ariz. l.j.") and not ("tran. l.j.") and not ("admin. l.j.") and not ("technology l.j.") and not ("transnat'l l.j.") and not ("indus. rel. l.j.") and not ("industrial relations l.j.") and not ("ind. rel. l.j.") and not ("trade l.j.") and not ("n.y.l.j.") and not ("comm. reports") and not ("law review commission") and not ("law rev. comm") and not ("law rev. commn") and not ("law rev. com.") and not ("tax law rev.") and not ("law review") and not ("law journal") and not ("l.rev.") and not ("law rev.") and not ("j.l.") and not ("l. jour.") and not ("jour. l.") and not ("journal of law") and not ("l.q.") and not ("pol'y") and not ("j. envtl.") and not ("j. pub.") and not ("j. int'l l.") and not ("j. corp. l.") and not ("j. crim. l.") and not ("j. const. l.") and not("int'l comp. l.") and not ("j. fam. l.") and not ("notre dame law."). 
exception of a small handful with only one citation over the course of 1945-2018 that could not be included in the search string due to Lexis Advance's character limit.

Next, since I excluded various commercial or other non-academic publications such as New York Law Journal or Administrative Law Review, from my initial searches using Lexis Advance's and not function, I then ran searches for these journals independently and added back those opinions that also cited to academic journals. ${ }^{135}$

Additionally, after discovering that many courts used the abbreviations "l.r." for "law review" or "law j." for "law journal," I ran separate searches for opinions citing academic law journals using those abbreviations while also crafting my search to exclude false positives and prevent double-counting opinions already included in previous searches to the greatest extent possible. ${ }^{136}$

135 This was accomplished by searching for ("admin. l. rev.") \& DA (aft 12-31-1944), then using Lexis' "Search within" feature to highlight the terms "l. rev. OR "j.l." OR "l.j." Once the terms were highlighted in my results list, I could sort by "Reported" under "Publication Status," sort by date, then tally any results that also cited to academic legal periodicals.

136 My "L.R." Search: "univ. l.r." OR "u. l.r." OR "harv. l.r." OR "harvard l.r." OR "harvard lr" OR "harv lr" OR "colum. l.r" OR "columbia l.r." OR "columb. l.r." OR "columbia lr" OR "stan. l.r." OR "stanford l.r." OR "cornell l.r." OR "cornell lr" OR "chi.l.r." OR "chicago l.r." OR "chi lr" OR "rts. l.r." OR "akron l.r." OR "ala. l.r." OR "alabama l.r." OR "alaska l.r." OR "alb. l.r." OR "albany l.r." OR "am. crim. l.r." OR "am. u. l.r." OR "ariz. l.r." OR "arizona l.r." OR "ark. l.r." OR "baylor l.r." OR "brooklyn l.r." OR "buff. l.r." OR "buffalo l.r." OR "buff. crim. l.r." OR "cardozo l.r." OR "w. res. l.r." OR "western res. l.r." OR "chicago-kent l.r." OR "cath. l.r." OR "chi-kent l.r." OR "clev. st. l.r." OR "cleve. st. l.r." OR "conn. l.r." OR "col. l.r." OR "c.r.-c.l. l.r." OR "creighton l.r." OR "cumberland l.r." OR "dakota l.r." OR "depaul l.r." OR "dick. l.r." OR "dickinson l.r." OR "drake l.r." OR "drexel l.r." OR "duq. l.r." OR "duquesne l.r." OR "fordham l.r." OR "ind. comm. l.r." OR "ga. l.r." OR "wash. l.r." OR "gonzaga l.r." OR "houston l.r." OR "hous. l.r." OR "new eng. l.r." OR "bus. l.r." OR "tech. l.r." OR "hofstra l.r." OR "idaho l.r." OR "iowa l.r." OR "kan. l.r." OR "kansas city l.r." OR "la. l.r." OR "loy. l.r." OR "loyola l.r." OR "l.a. l.r." OR "marq. l.r." OR "marquette l.r." OR "mercer l.r." OR "md. l.r." OR "mich. l.r." OR "michigan l.r." OR "minn. l.r." OR "minnesota l.r." OR "mo. l.r." OR "mont. l.r." OR "mtn. l.r." OR "neb. l.r." OR "n.c. l.r." OR "n.m. l.r." OR "n. ky. l.r." OR "nova l.r." OR "northwestern l.r." OR "dame l.r." OR "nyu lr" OR "pepp. l.r." OR "pepperdine l.r." OR "rutgers l.r." OR "john's l.r." OR "diego l.r." OR "clara l.r." OR "seton hall l.r." OR "smu l.r." OR "s. tex. l.r." OR "cal. l.r." OR "johns l.r." OR "louis l.r." OR "suffolk l.r." OR "syracuse l.r." OR "tax l.r." OR "cooley l.r." OR "marshall l.r." OR "tul. l.r." OR "tulane l.r." OR "ucla l.r." OR "u.c.l.a. l.r." OR "balt. l.r." OR "u.c. davis l.r." OR "u.m.k.c. l.r." OR "umkc l.r." OR "cin. l.r." OR "cincinnati l.r." OR "u. colo. l.r." OR "dayton l.r." OR "water l.r." OR "mercy l.r." OR "fla. l.r." OR "ill. l.r." OR "miami l.r." OR "okla. l.r." OR "pa. l.r." OR "penn. l.r." OR "pitt. l.r." OR "pittsburgh l.r." OR "rich. l.r." OR "tenn. l.r." OR "tex. l.r." OR "tol. l.r." OR "toledo l.r." OR "tulsa l.r." OR "utah l.r." OR "vand. l.r." OR "vanderbilt l.r." OR "vand lr" OR "vill. l.r." OR "villanova l.r." OR "va. l.r." OR "forest l.r." OR "wash. lee l.r." OR "va lr" OR "washington l.r." OR "wayne l.r." OR "wayne lr" OR "western l.r." OR "wm. mary l.r." OR "wm. mitchell l.r." OR "wis. l.r." OR "wyo. l.r." \& DA (aft 12-31-1944) and not ("l.j.") and not ("j.l.") and not ("l. jour.") and not ("jour. l.") and not ("l. rev.") and not ("law review") and not ("law journal") and not ("journal of law") and not ("d. ala. l.r.") and not ("d. alaska l.r.") and not ("dist. alaska l.r.") and not ("l.r. co.") and not ("d. pa. l.r.") and not ("pa. l.r.b.") and not ("pa. l.r. bd") and not ("d. va. l.r.") and 
not ("d. w.va. l.r.") and not ("va. l.r. civ.") and not ("va. l.r.n.s.") and not ("d. wash. l.r.") and not ("d. wis. l.r.") and not ("d. ariz. l.r.") and not ("d. cal. l.r.") and not ("dist. cal. l.r.") and not ("d. ill. l.r.") and not ("d. minn. l.r.") and not ("d. md. l.r.") and not ("d. mich. l.r.") and not ("d. tex. l.r.") and not ("d. mo. l.r.") and not ("d. iowa") and not ("dist. iowa") and not ("l.r. co.") and not ("iowa l.r.a.") and not ("d. neb. l.r.") and not ("d. mont. l.r.") and not ("d. la. l.r.") and not ("d. n.c. l.r.") and not ("d. fla. l.r.") and not ("d. okla. l.r.") and not ("d. tenn. l.r.") and not ("d. ga. l.r.") and not ("buffalo l.r. ry.") and not ('buffalo l.r.r.") and not ("district of michigan l.r.") and not ("d. conn. l.r.") and not ("d. idaho l.r.") and not ("dist. idaho") and not ("d. kan. l.r.") and not ("l.r. hannen, burlington") and not ("hatch v. cincinnati") and not ("pittsburgh l.r. rd.") and not ("utah l.r.b.") and not ("utah l.r. board") and not ("utah l.r. gardiner") and not ("d.n.m. l.r.") and not ("ass'n m.l.r.b.") and not ("n.m.l.r. civ. 7.1") and not ("d. va. lr") and not ("va lr civ.") and not ("d. wyo. l.r.") and not ("arizona l.r. civ.") and not ("arizona l.r.b.p.") and not ("dakota l.r. foy") and not ("dakota l.r. 1.3") and not ("gray nova l.r.'s mother") and not ("on the bus l.r. testified") and not ("22 cal. l.r.").

This was my "Law J." search string: ("yale law j." OR "georgetown law j." OR "hastings law j." OR "duke law j." OR "alb. law j." OR "albany law j." OR "cornell law j." OR "emory law j." OR "ind. law j." OR "indiana law j." OR "rutgers law j." OR "widener law j." OR "geo. law j." OR "n.c. cent. law j." OR "miss. law j." OR "ill. law j." OR "tex. law j." OR "texas law j." OR "ky. law j." OR "hast. law j." OR "tech. law j." OR "depaul bus. law j." OR "berkeley bus. law j." OR "hastings bus. law j." OR "duq. bus. law j." OR "rutgers bus. law j." OR "entrepen. bus. law j." OR "davis bus. law j." OR "vand. law j." OR "u.p.r. bus. law j." OR "rico bus. law j." OR "nevada law j." OR "chi. law j." OR "kentucky law j." OR "mary's law j." OR "marys law j." OR "ohio law j." OR "nev. law j." OR "denver law j." OR "brandeis law j." OR "basin law j." OR "hall law j." OR "st. thomas law j." OR ("hamline law j.") OR ("willamette law j.") OR "little rock law j." OR "ualr law j." OR "washburn law j." OR "wash. law j." OR "u. ark. law j." OR "hasting law j." OR "tulsa law j." OR "wyoming law j." OR "blackletter law j." OR "coastal law j." OR "wyo. law j." OR "nova law j." OR "denv. law j." OR "den. law j." OR "louis law j." OR "howard law j." OR "how. law j." OR "cam. law j." OR "camden law j." OR "u.a.l.r. law j." OR "marshall law j." OR "state law j." OR "u. law j." OR "univ. law j." OR "university law j." OR "det. law j." OR "envtl. law j." OR "envt. law j." OR "env. law j." OR "environmental law j." OR "st. law j." OR "const. law j." OR "constitutional law j." OR "world law j." OR "admin. law j. am." OR "pac. law j." OR "pacific law j." OR "sci. law j." OR "law j. sci." OR "md. law j." OR "int'l law j." OR "intl. law j." OR "international law j." OR "interest law j." OR "int. law j." OR "hofstra lab. law j." OR "hofstra labor law j." OR "comp. lab. law j." OR "comporative labor law. j." OR "educ. law j." OR "education law j." OR "prop. law j." OR "property law j." OR "can.-u.s. law j." OR "ent. law j." OR "entertainment law j." OR "conn. ins. law j." OR "elder law j." OR "fed. comm. law j." OR "urb. law j." OR "urban law j." OR "women's law j." OR "rights law j." OR "rts. law j." OR "rits. law j." OR "immigr. law j." OR "immigration law j." OR "gaming law j." OR "emp. law j." OR "empl. law j." OR "employment law j." OR "bus. com. law j." OR "tax law j." OR "sports law j." OR "mar. law j." OR "maritime law j." OR "con. law j." OR "black law j." OR "dev. law j." OR "resol. law j." OR "quinnipiac health law j." OR "quinnipiac probate law j." OR "quinnipiac probate law j." OR "conn. prob. law j." OR "detroit law j." OR "conn. probate law j." OR "interdisc. law j." OR "interdis. law j." OR "interdisciplinary law j." OR "transp. law j." OR "trans. law j." OR "commercial law j." OR "asian am. law j." OR "asian law j." OR "actec law j." OR "tch. law j." OR "reserve law j." OR "indian law j." OR "computer law j." OR "drug law j." OR "cosm. law j." OR "raza law j." OR "ohio state law j." OR "dame law j." OR "loy. law j." OR "southwestern law j." OR "u. chicago law j." OR "mich. law j." OR "will. law j." OR "geor. l.j." OR "harvard law j." OR "envt'l law j." OR "tul. law j." OR "tulane law j." OR "ethnic anc. law j." OR "software law j." OR "s.w. law j." OR "southwestern law j." OR "comp. law j." OR "comparative law j." OR "u.s.-mex. law j." OR "poverty law j." OR "phoenix law j." OR "ariz. law j." OR "transportation law j." OR "admin. l.j." OR "administrative law j." OR "technology law j." OR "transnat'l law j." OR "transnational law j." OR "indus. rel. law j." OR "industrial relations law j." OR "ind. rel. law j." OR "trade law j.") \& DA (aft 12-31-1944 \& bef 01-01-2019) and not ("n.y.l.j.") and not ("comm. reports") and not ("law review commission") and not ("law rev. comm") and not ("law rev. commn") and not 
Finally, I crafted searches for citations to all academic journals excluded from my previous searches attempting to exclude opinions citing to those journals that were

("law rev. com.") and not ("tax law rev.") and not ("law review") and not ("law journal") and not ("l.rev.") and not ("law rev.") and not ("j.l.") and not ("l. jour.") and not ("jour. l.") and not ("journal of law") and not ("l.q.") and not ("pol'y") and not ("j. envtl.") and not ("j. pub.") and not ("j. int'l l.") and not ("j. corp. l.") and not ("j. crim. l.") and not ("j. const. l.") and not("int'l comp. l.") and not ("j. fam. l.") and not ("notre dame law."). 
already included in my previous totals. ${ }^{137}$ I then scanned these results to ensure no false positives were included. 138

137 The search string for citations excluded from my initial "L.R." query: ("az. l.r." OR "int'l l.r." OR "pennsylvania l.r." OR "gate l.r." OR "puget sound l.r." OR "u. of hawaii l.r." OR "wesleyan l.r." OR "l. sch. l.r." OR "n.c. cent. l.r." OR "univ. ill. l.r." OR "seattle l.r." OR "u. of ill. l.r." OR "touro l.r." OR "miss. c.l.r." OR "gonz. l.r." OR "vanderbilt lr" OR "geo. mason l.r." OR "u.s.f. l.r." OR "coll. l.r." OR "evtl. aff. l.r." OR "int'l comp. l.r" OR "mary's l.r." OR "liberties l.r." OR "willamette l.r." OR "widener l.r." OR "whittier l.r." OR "washburn l.r." OR "southwestern l.r." OR "richmond l.r." OR "u.s.f. l.r." OR "francisco l.r." OR "samford l.r." OR "denver l.r." OR "u.d.c. l.r." OR "f.s.u. l.r." OR "ohio state l.r." OR "cal. davis l.r." OR "valpo l.r." OR "valparaiso l.r." OR "william mary l.r." OR "northern l.r." OR "cleveland state l.r." OR "ucd l.r." OR "uc davis l.r." OR "amer. crim. l.r." OR "new crim. l.r." OR "boston college l.r." OR "stetson l.r." OR "byu l.r." OR "cal. w. l.r." OR "cath. l.r." OR "mex. l.r." OR "louisiana l.r." OR "kansas l.r." OR "or. l.r." OR "n.d. l.r." OR "s.c. l.r." OR "me. l.r." OR "nebraska l.r." OR "vt. l.r." OR "oklahoma l.r." OR "oregon l.r." OR "virginia l.r." OR "carolina l.r." OR "car. l.r." OR "baltimore l.r." OR "s.w. l.r." OR "s.d. l.r.") \& DA (aft 12-31-1944 \& bef 01-01-2019) and not ("l.r.s.") and not ("l.r.a.") and not ("l.r. bd.") and not ("n.s.w.l.r.") and not ("d. kansas l.r.") and not ("dist. of new mex. l.r.") and not ("d. new mex. l.r.") and not ("d. louisiana l.r.") and not ("d. pennsylvania l.r.") and not ("pennsylvania l.r. board") and not ("pennsylvania l.r.b.") and not ("d. s.d.") and not ("d. vt.") and not ("district of nebraska") and not ("me. l.r.b.") and not ("d. me.") and not ("d. az. l.r.") and not ("d. s.c.") and not ("d.n.d. l.r.") and not ("n.y.n.d. l.r.") and not ("d. or.") and not ("l.j.") and not ("comm. reports") and not ("law review commission") and not ("law rev. comm") and not ("law rev. commn") and not ("law rev. com.") and not ("tax law rev.") and not ("law review") and not ("law journal") and not ("l.rev.") and not ("law rev.") and not ("j.l.") and not ("l. jour.") and not ("jour. l.") and not ("journal of law") and not ("l.q.") and not ("pol'y") and not ("j. envtl.") and not ("j. pub.") and not ("j. int'l l.") and not ("j. corp. l.") and not ("j. crim. l.") and not ("j. const. l.") and not("int'l comp. l.") and not ("j. fam. l.") and not ("notre dame law.").

My final excluded citations search string: ("va. l. weekly" OR "cal. reg. l. rep." OR "intel. prop. rev." OR "j.c.l. c.r." OR "j. envt'l admin. l." OR "j. global trade" OR "nat. l. f." OR "pitt. tax rev." OR "ind. legal f." OR "j. afr.-am. l." OR "rich. j. global l." OR "civ. l.f." OR "j. sci. tech. envtl. l." OR "intell. prop. j." OR "j. envtl. pub. health l." OR "inst. on mineral" OR "j. prac. clinical l." OR "rev. ent. sports l." OR "j. int'l media" OR "j. food l." OR "j. health hosp. l." OR "j.l. soc'y" OR "mary pol'y rev." OR "juris rev." OR "l. bus. rev. am." OR "j. int'l arb." OR "j. pub. int'l l." OR "j. tax l." OR "j. asian l." OR "j. equine" OR "j. chinese l." OR "j. racial ethnic" OR "j. on legal malpractice" OR "j. comp. corp. l." OR "rev. int'l l." OR "major tax plan." OR "pub. int. l. rep." OR "j.c.r. econ." OR "world pub. ord." OR "int'l l.f." OR "ind. l.f." OR "loyola l.j." OR "depaul l.j." OR "camd. l.j." OR "southwest l.j." OR "so. tx. l.j." OR "suffolk t. l.j." OR "hasings l.j." OR "adm. l.j." OR "intenatl l.j." OR "williamette l.j." OR "ann. surv. mass. l." OR "dakota bar briefs" OR "chi.-kent rev." OR "contemporary law pamphlets" OR "denver law center journal" OR "denv. l. ctr. j." OR "hastings con." OR "hastings constitutional law quarterly" OR "j. radio l." OR "natural law forum" OR "nat. res. j." OR "iowa law bulletin" OR "nebraska law bulletin" OR "s. car. l.q." OR "int'l l. forum" OR "l. sch. record" OR "ill. l.q.")\& DA (aft 12-31-1944 \& bef 01-01-2019) and not("law review") and not("law journal") and not("l.rev.") and not("law rev.") and not ("j.l.") and not("l. jour.") and not("jour. l.") and not("journal of law") and not("n.y.l.j.") and not("pol'y") and not("j. envtl.") and not("j. pub.") and not("j. int'l l.") and not("j. corp. l.") and not("j. crim. l.") and not("j. const. l.") and not("int'l comp. l.") and not("j. fam. l.") and not("notre dame law.") and not ("yale l.j.") and not ("georgetown l.j.") and not ("hastings l.j.") and not ("duke l.j.") and not ("alb. l.j.") and not ("albany l.j.") and not ("cornell l.j.") and not ("emory l.j.") and not ("ind. l.j.") and not ("indiana l.j.") and not ("rutgers l.j.") and not ("widener l.j.") and not ("geo. l.j.") and not ("n.c. cent. l.j.") and not ("miss. l.j.") and not ("ill. l.j.") and not ("tex. l.j.") and not ("texas l.j.") and not ("ky. l.j.") and not ("hast. l.j.") and not ("tech.l.j.") and not ("depaul bus.") and not ("berkeley bus. l.j.") and not ("hastings bus. l.j.") and not ("duq. bus. l.j.") and not ("rutgers bus. l.j.") 
I believe these searches were as comprehensive as possible, but due to potential citation discrepancies in the opinions and potential human error, including every citation over the period studied is impossible. That being said, I am confident that the results are as accurate as possible, despite these limitations.

In terms of compiling my results, since my data represents opinions citing journals rather than total citations, multiple citations in an opinion were not counted. Therefore, if an opinion cited more than one journal in Part I or if an opinion cited a particular journal title more than once, or multiple journal titles within the same group in Part II, the additional citations were not added to the total. I also did not differentiate between majority opinions, dissents or concurrences, nor did I account for a negative or critical citation of an article. Essentially, if my searches indicated a reference to an academic legal periodical anywhere in an opinion, it was added to my total.

I also did not account for differences in page numbers per volume for the different journal titles, which provides an advantage to more voluminous or more regularly published journals as they produce more material that could potentially be cited by a court. ${ }^{139}$ Other scholars have attempted to account for this advantage by

and not ("entrepen. bus. l.j.") and not ("davis bus. l.j.") and not ("vand. l.j.") and not ("u.p.r. bus. l.j.") and not ("rico bus. l.j.") and not ("nevada l.j.") and not ("chi. l.j.") and not ("kentucky l.j.") and not ("mary's l.j.") and not ("marys l.j.") and not ("ohio l.j.") and not ("nev. l.j.") and not ("denver l.j.") and not ("brandeis l.j.") and not ("basin l.j.") and not ("hall l.j.") and not ("thomas l.j.") and not ("hamline l.j.") and not ("willamette l.j.") and not ("rock l.j.") and not ("ualr l.j.") and not ("washburn l.j.") and not ("wash. l.j.") and not ("u. ark. l.j.") and not ("hasting l.j.") and not ("tulsa l.j.") and not ("wyoming l.j.") and not ("blackletter l.j.") and not ("coastal l.j.") and not ("wyo. l.j.") and not ("nova l.j.") and not ("denv. l.j.") and not ("den. l.j.") and not ("louis l.j.") and not ("howard l.j.") and not ("how. l.j.") and not ("cam. l.j.") and not ("camden l.j.") and not ("u.a.l.r. l.j.") and not ("marshall l.j.") and not ("state l.j.") and not ("u. l.j.") and not ("univ. l.j.") and not ("det. l.j.") and not ("envtl. l.j.") and not ("envt. l.j.") and not ("env. l.j.") and not ("st. l.j.") and not ("const. l.j.") and not ("world l.j.") and not ("admin l.j. am.") and not ("pac. l.j.") and not ("pacific l.j.") and not ("sci. l.j.") and not ("l.j. sci.") and not ("y.l.j.") and not ("md. l.j.") and not ("int'l l.j.") and not ("intl. l.j.") and not ("international l.j.") and not ("interest l.j.") and not ("int. l.j.") and not ("hofstra lab. l.j.") and not ("comp. lab. l.j.") and not ("educ. l.j.") and not ("prop. l.j.") and not ("can.-u.s. l.j.") and not ("ent. l.j.") and not ("entertainment l.j.") and not ("conn. ins. l.j.") and not ("elder l.j.") and not ("fed. comm. l.j.") and not ("urb. l.j.") and not ("urban l.j.") and not ("women's l.j.") and not ("rights l.j.") and not ("rts. l.j.") and not ("rits. l.j.") and not ("immigr. l.j.") and not ("immigration l.j.") and not ("gaming l.j.") and not ("emp. l.j.") and not ("empl. l.j.") and not ("bus. com. l.j.") and not ("tax l.j.") and not ("sports l.j.") and not ("mar. l.j.") and not ("maritime l.j.") and not ("con. l.j.") and not ("black l.j.") and not ("dev. l.j.") and not ("resol. l.j.") and not ("quinnipiac health l.j.") and not ("quinnipiac prob. l.j.") and not ("quinnipiac probate l.j.") and not ("hofstra labor l.j.") and not ("conn. prob. l.j.") and not ("detroit l.j.") and not ("conn. probate l.j.") and not ("interdisc. l.j.").

138 Some academic legal periodicals used such common names they had to be excluded from my results, for example, a search for the University of Michigan Journal of Law Reform's previous title, Prospectus, returns over 5,000 opinions unrelated to the journal.

139 See Olavi Maru, Measuring the Impact of Legal Periodicals, 1976 AM. B. Found. RES. J. 227, 24041 (1976) ("Other things being equal, a journal with more citable material may be expected to be cited more often than one with less citable material."). 
measuring citations per article, ${ }^{140}$ citations per page, ${ }^{141}$ and even citations per word. ${ }^{142}$ Given, however, that my study looked at judicial citations to all academic law journals as well as citations to groupings of law reviews rather than particular volumes or years, these options were not practical, nor would they have added measurably to my analysis. ${ }^{143}$

${ }^{140}$ Fred R. Shapiro, The Most-Cited Law Reviews, 29 J. Legal STUD. 389, 392 (2000). ${ }^{141}$ Leonard, supra note 90, at 193-94.

142 Perry, supra note 73, at 10.

${ }^{143} I d$. at 10-11 ("Total citations are the best measure of the overall influence of each journal ... The journal that publishes more text is more valuable in the sense that it contributes more to the legal discourse ... As long as impact per se is a valid measure of quality (in the aggregate sense), citation frequency is a legitimate ranking criterion. On the other hand, using standardized citation rates (such as citations per $x$ words, or even citations per article) better reflects average academic quality."). 